\title{
Stratigraphic style of coal and non-marine strata in a high accommodation setting: Falher Member and Gates Formation (Lower Cretaceous), western Canada
}

\author{
Jennifer Wadsworth, Ron Boyd, Claus Diessel \\ Department of Geology \\ University of Newcastle \\ Callaghan, NSW, 2308 \\ Australia
}

\author{
DALE LECKIE \\ Nexen Inc. \\ 801 - 7th Ave. $S W$ \\ Calgary, $A B \quad T 2 P 3 P 7$
}

\begin{abstract}
The Lower Cretaceous Falher Member and Gates Formation of the Western Canadian Sedimentary Basin provide an opportunity to investigate high resolution stratigraphic correlation in non-marine to marginal marine rocks. This is due to the large volume of high-quality data available from subsurface cores and wireline logs in the Elmworth area, corresponding outcrops in the adjacent Rocky Mountains foothills, and outcrop and continuous core data from the Bullmoose Mine area in northeastern British Colombia.

A key component of the high resolution interpretation and correlation in this region is the abundant, thick coal seams that occur in fresh mine highwalls and also in cores from the mine sites and the Elmworth area. Using coal petrographic constituent analysis and derived parameters, we are able to identify systematic variations in coal properties that respond to changes in accommodation. In particular, these properties enable us to distinguish two types of peat (transgressive and regressive) characterized by wetting- and drying-upward behaviour linked to variations in the groundwater table. They also enable recognition of a range of non-marine stratigraphic surfaces that record responses to changing accommodation, including accommodation reversal surfaces, flooding surfaces, hiatal surfaces, paludification surfaces and terrestrialization surfaces. A combination of these coal parameters, together with the facies characteristics of the surrounding non-marine and marginal marine rocks, enables recognition of distinctive high-resolution stratigraphic signatures in the rocks. This in turn provides a previously unavailable ability to correlate stratigraphic units from their downdip marine position, through the shoreline zone and into the terrestrial realm.

For the Falher/Gates unit, we recognize nine regionally correlatable cycles over a vertical distance of around $300 \mathrm{~m}$ and a lateral distance of $80 \mathrm{~km}$ downdip and $150 \mathrm{~km}$ along strike. The basis for this detailed correlation is the similarity of the accommodation trends as seen in both the organic and clastic facies. Results show that earlier concepts of parasequences and their flooding surface boundaries in marine rocks need to be significantly modified in the terrestrial realm. Sharp hiatal parasequence boundaries in the marine realm such as flooding surfaces and wave/tidal ravinement surfaces may correlate updip to packages of rocks that pass gradationally from transgressive to regressive units and preserve the transitions between the two. Non-marine sediments may accumulate during and following shoreline regression, and prior to and during shoreline transgression. The exact style and preservation of the non-marine stratigraphic package depends on the local balance between accommodation and sediment flux at the time of deposition. Coals occur in both regressive and transgressive styles and may initiate or terminate parasequences. Coals may also occur as compound coals that span more than one parasequence and contain internal discontinuity surfaces.
\end{abstract}

\section{RÉSUMÉ}

Le Membre Falher du Crétacé inférieur et la Formation Gates du bassin sédimentaire de l'Ouest canadien fournissent l'opportunité d'enquêter sur la corrélation stratigraphique à haute résolution de roches du type non marines à marines marginales. Ceci est possible grâce au volume important de données disponibles de haute qualité provenant de carottes du sous-sol et de diagraphies différées de la région d'Elmworth, correspondant aux affleurements des piémonts adjacents des Montagnes Rocheuses, et aux affleurements et aux données de carottes continues provenant de la Mine Bullmoose dans le nord-est de la Colombie Britannique. 
Des couches épaisses de charbon qui se trouvent dans les hautes structures de mines fraîches, ainsi que dans les carottes provenant de sites de mines et de la région d'Elmworth représentent une composante clé dans l'interprétation et la corrélation à haute résolution dans cette région. Au moyen d'analyse pétrographique des constituants du charbon et de paramètres dérivés, nous sommes en mesure d'identifier les variations systématiques des propriétés du charbon répondant aux changements dans l'espace d'accommodation. Ces propriétés nous permettent en particulier de distinguer deux types de tourbe (transgressive et régressive) qui sont caractérisées par un comportement ascendant humide-et-sec relié aux variations de le surface libre de la nappe phréatique. Elles permettent également la reconnaissance d'une variété de surfaces stratigraphiques non marines qui enregistrent des réponses aux changements de l'espace d'accommodation, incluant les surfaces liées aux inversions de l'espace d'accommodation, de surfaces inondées, de surfaces hiatales, de surfaces de paludification et de surfaces terrestres. La combinaison de ces paramètres de charbon avec les caractéristiques $\mathrm{du}$ faciès des roches non marines et des roches marines marginales environnantes permet la reconnaissance de signatures stratigraphiques à hautes résolutions distinctives dans les roches. Ceci à son tour fournit une capacité pour corréler les unités stratigraphiques à partir de leur position marine en aval-pendage, ensuite à travers la zone de la ligne de rivage et jusque dans la région terrestre, ce qui n'était pas disponible antérieurement.

En ce qui concerne l'unité Falher/Gates, nous reconnaissons neuf cycles régionaux corrélationnels sur une distance verticale d'environ $300 \mathrm{~m}$ et sur une distance latérale de $80 \mathrm{~km}$ en aval-pendage et sur $150 \mathrm{~km}$ en direction du plan géologique. L'élément principal de cette corrélation détaillée est dans la similarité entre les tendances des espaces d'accommodation comme l'indiquent à la fois les faciès organiques et clastiques. Les résultats montrent que les concepts antérieurs de paraséquences et de leurs limites de surface d'inondation dans les roches marines ont besoin d'être modifiées de manière significative dans la région terrestre. Des limites de paraséquences hiatales acérées dans la région terrestre telles que des surfaces inondées et des surfaces de ravinement d'ondes/marées peuvent être corrélées à un ensemble de roches qui passent graduellement d'unités transgressives à des unités régressives et préservent les transitions entre les deux. Les sédiments non marins peuvent s'accumuler pendant et en suivant la régression de la ligne de rivage, de même qu'avant et pendant la transgression de la ligne de rivage. Le style exact et la préservation de l'ensemble stratigraphique non marin dépendent de l'équilibre local entre l'espace d'accommodation et le flux de sédiments au moment de la déposition. Les charbons de styles régressifs et transgressifs sont présents et peuvent initier ou terminer les paraséquences. Les charbons peuvent aussi être présents comme charbons composés ayant une portée de plus d'une paraséquence et pouvant contenir des surfaces de discontinuité interne.

Traduit par Gabrielle Drivet

\section{INTRODUCTION}

The non-marine realm is the next frontier to be modeled using sequence stratigraphic principles (e.g. Sprague et al., 2002). The original focus of sequence stratigraphy was on nearshore and shallow-marine strata because they were primary economic targets and readily subdivided by chronostratigraphic surfaces (e.g. Posamentier and Vail, 1988; van Wagoner et al., 1990). In these environments, variations in accommodation (relative to sediment supply) can be identified by facies changes, changes in depth indicators such as trace and body fossils, and the occurrence of widespread, correlatable surfaces associated with the transgressive and regressive passage of the shoreline. Variations in accommodation control the development of systems tracts, the building blocks in a sequence stratigraphic framework. This framework has yet to be reliably extended into non-marine strata, mainly because individual stratigraphic units are difficult to identify; marker beds are less common and continuous; and chronostratigraphic and biostratigraphic control is commonly lacking or inadequate.

The principles of accommodation (Jervey, 1988) offer the best method to develop a systematic approach to non-marine sequence stratigraphy. This is because other approaches such as facies models and architectural element analysis, although offering local methods to interpret non-marine successions, do not provide a unified approach to encompass all non-marine strata, and do not provide a link to adjacent coastal and marine strata. Accommodation is the space available for sediment accumulation derived from changes in tectonic and eustatic driving forces (Jervey, 1988). The characteristics of the sedimentary basin response can then be considered to result from the magnitude and variability of the accommodation and sediment flux.

Our aim is to document the influence of accommodation on non-marine strata and to develop a summary model of non-marine sequence stratigraphy. We define non-marine here to encompass both the paralic (marine-influenced) and continental (no direct marine influence) realms, landward of the shoreline. Because this is not an easy boundary to pick in the rock record, we prefer to use the term non-marine rather than attempt to subdivide into the two separate subenvironments. We have conducted a series of field studies of coal-bearing non-marine strata in the Western Canadian Sedimentary Basin (WCSB; Leckie and Smith, 1992) from a range of accommodation settings. A major advantage of the WCSB for our study is the high-quality, publicly available subsurface database, enabling access to thousands of wireline logs and cores for our project. This paper presents detailed field studies of the subsurface Falher Member of the Spirit River Formation and outcrop of the Gates Formation (Mannville 


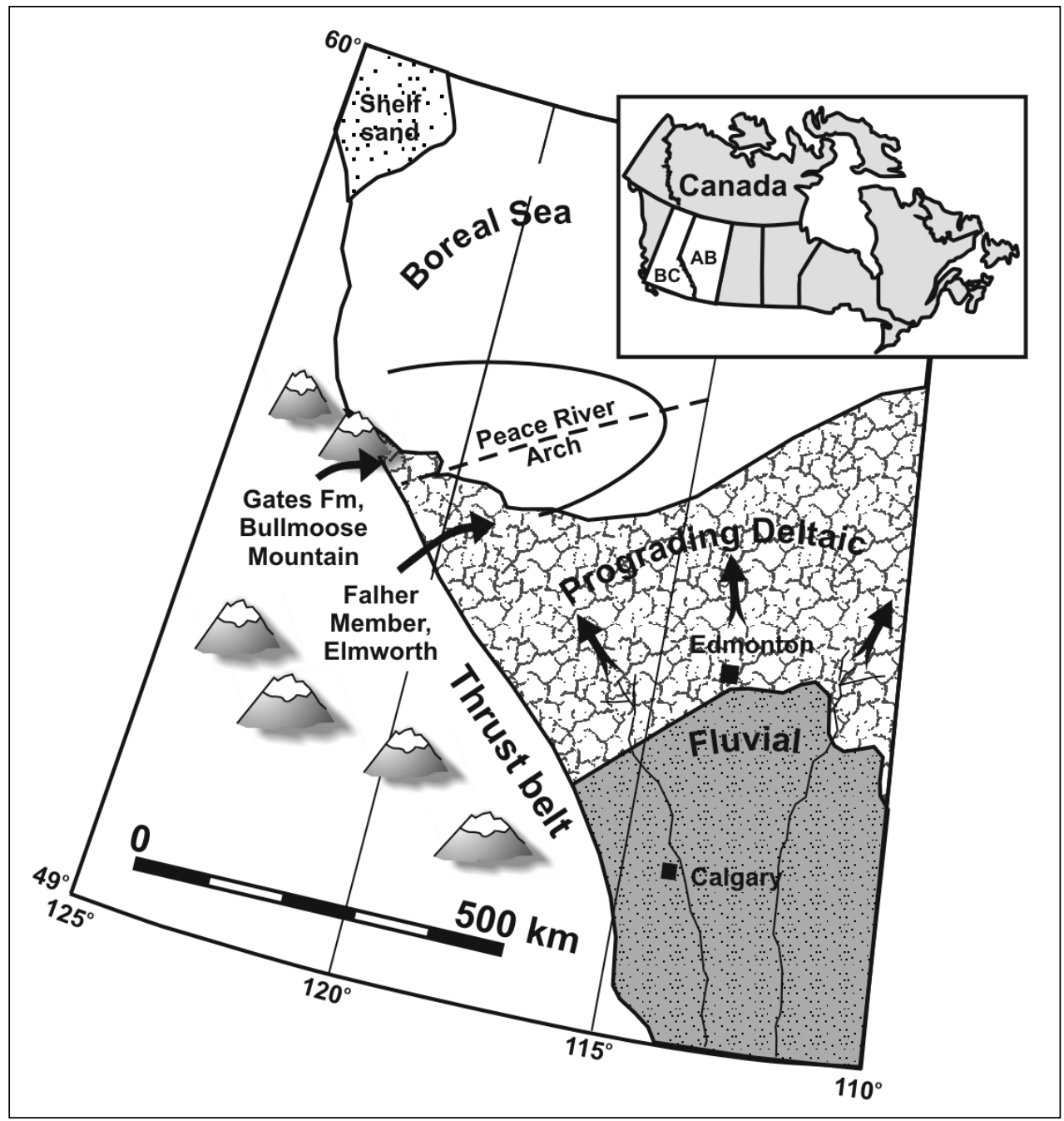

Fig. 1. Paleogeographic reconstruction of the Upper Mannville (Albian) Falher and Gates units (from Leckie and Smith, 1992). The shoreline trend was approximately east-west near the thrust belt. Both the outcrop study area near Bullmoose Mountain and the subsurface study area in the Elmworth Field (indicated by arrows) may have been influenced by differential subsidence associated with the former Peace River Arch.

Group) of northwest Alberta and northeast British Colombia (Leckie, 1986a; Diessel et al., 2000), near the foredeep margin of the basin (Fig. 1). These two units are stratigraphically equivalent, and allow comparison between co-eval peat development in high to very high accommodation settings. This study provides the end member in a spectrum between other WCSB detailed studies conducted by our group, with low accommodation settings studied in the Basal Quartz Formation (Zaitlin et al., 2002) and the Lower Cretaceous of southern Alberta and Saskatchewan (Leckie et al., 1997), and intermediate accommodation settings investigated in the Upper Mannville Group of central Alberta (Wadsworth et al., 2002; Chalmers, 2002).

Previous studies (e.g. Diessel, 1992; Diessel et al., 2000; McCarthy and Plint, 2001) have illustrated the significance of key lithologies such as paleosols, lacustrine strata, and coal in understanding non-marine stratigraphy. We have chosen to concentrate on the coal-bearing strata because of their abundance and variability in the study area, and their potential to provide information on groundwater fluctuations, a critical accommodation parameter. The objectives of this study are: 1) to document the style of non-marine stratigraphy that characterizes a high-accommodation setting, and 2) to investigate the role of coal-bearing strata in non-marine successions and use their properties as a tool for detailed stratigraphic interpretation and correlation. Results from this study will provide a better understanding of the factors controlling non-marine stratigraphy in high-accommodation areas. These factors include the influence of basement topography; the accumulation, stacking patterns, preservation and splitting of peat; the development of non-marine flooding surfaces; and the paucity of incised valleys fills.

\section{An Approach to Non-Marine Sequence Stratigraphy}

Recognition of accommodation cycles linked to relative sea level cycles, and surfaces of sequence stratigraphic significance 
in non-marine strata is inherently more difficult than in marine deposits (e.g. Plint et al., 2001). An exception to this occurs when the terrestrial rocks contain paralic coals. Coals formed in deltaic and coastal-plain settings have a well documented compositional cyclicity (e.g. Snedden and Kersey, 1981; Heckel, 1986; Diessel, 1992) because the original peat bodies were affected by marine influences as their groundwater tables responded to relative changes of sea level. Organic matter reacts with great sensitivity to groundwater oscillations, affecting $\mathrm{pH}$ and redox potentials so that even weak changes in the hydrologic regime of peat mires may be translated into compositional differences in the subsequent coal seams (Cecil et al., 1979; Frenzel, 1983). Because of the genetic dependence in coastal settings of groundwater position on sea level and, in many cases, their considerable lateral extent, paralic coal seams provide a good non-marine indication of relative sea level variations. However, in the literature, the sequence-stratigraphic interpretation of coal measures has mostly made use of the geometry, stacking pattern, and position of whole coal seams within paralic depositional cycles (Aitken and Flint, 1995; Hampson et al., 1999, 2001; Montgomery et al., 2001), and relatively few investigations have focussed on the significance of the internal composition and organization of coal seams (Diessel et al., 2000 and references therein).

Accommodation in a mire is defined as the maximum thickness to which a peat can accumulate (McCabe, 1993). To determine the usefulness of coal as a non-marine sequence stratigraphic tool, we examine the premise that variations in the balance between the rates of accommodation and peat production result in vertical changes in the composition of a coal seam (Fig. 2). Peat is only able to accumulate if environmental conditions allow peat production to occur and accommodation is sufficient to allow the peat to be preserved (Boyd and Diessel, 1994, 1995; Diessel and Boyd, 1994; Bohacs and Suter, 1997; Diessel et al., 2000). A compilation of Holocene maximum peat accumulation rates in relation to latitude (Fig. 2 in Diessel et al., 2000) indicates that rates of peat production may differ greatly amongst various climatic zones, but vary little within zones. This implies that imbalances in accommodation rate/peat production rate ratios are mainly due to changes in accommodation (Shanley and McCabe, 1994; Boyd and Diessel, 1994, 1995).

A number of petrographic indicators in coal show systematic variations with changing accommodation (see discussions in Diessel and Gammidge, 1998; Diessel et al., 2000) and can be used to identify two styles of peat formation. Figure 2 is a schematic model illustrating how cyclic changes in the accommodation rate/peat production rate can produce a single regressive-style coal seam followed by a transgressive-style seam. Mires in which the ratio of accommodation rate to peat production rate remains well-balanced (between 1 and 1.18) for a long period of time may lead to the formation of thick, often ombrotrophic (i.e. "raised") mires with minimum ash content and maximum tissue preservation (see Fig. 3 in Bohacs and Suter, 1997). Drying-upward conditions are indicated by a changing accommodation/peat production rate ratio from balanced (or high) to low. As the ratio drops to between 1 and 0.5 , the ash content of the peat increases because of oxidation and occasional burning of organic matter, leading to an "impure" coal. If the ratio falls below about 0.5 , peat cannot be preserved (even though it may still be produced, as occurs in a raised mire) and terrigenous sediments may be deposited instead. A negative ratio results in sediment exposure, erosion and reworking. In contrast, wetting-upward conditions are represented by a changing accommodation/peat production rate ratio from balanced (or low) to high. As the ratio rises from 1.18 to 1.5 , coal facies may grade from limnotelmatic to shaly coal (mineral content 30-50\%), to coaly shale (mineral content of $50-90 \%$ ), and finally to pure shale as peat production ceases. An accelerated accommodation rate causes frequent flooding of the peat which raises the adventitious mineral content, resulting in reduced thickness and quality of coal in areas away from the optimum peat-forming conditions.

Several non-marine sequence stratigraphic surfaces (Fig. 2) have been identified in coal (Diessel et al., 2000). Of greatest importance is the accommodation reversal surface (ARS) which delineates the surface across which accommodation conditions change from decreasing to increasing, or vice versa. Occurrence of this surface indicates whether the peat has formed on a single rising or falling limb of the accommodation curve. If a coal contains an ARS, then it is a composite seam spanning more than one cycle of relative sea level. The accommodation rate/peat production rate curve (Fig. 2) shows a range of deposits and surfaces which might form in a paralic environment during a single episode of increasing and decreasing accommodation conditions, with superimposed smaller-scale accommodation steps. The left hand side of the hypothetical curve shows, for simplicity, a peat seam containing multiple horizons that formed during decreasing accommodation conditions, such as occur at the final stages of the terrestrialization (Frenzel, 1983; Boron et al., 1987). Such peat corresponds to 'regressive' style coals (Diessel, 1992), that are separated from their underlying subaqueous floor sediments by a terrestrialization surface (TeS). This surface is commonly non-hiatal because as water depth and accommodation rates gradually decrease, there is no break in sedimentation but rather a shift from predominantly allochthonous clastic sedimentation to autochthonous peat accumulation. The subsequent coal represents a continuation of the shoaling-upwards succession, and typically contains one or more drying-up units reflecting smaller-scale accommodation variation. The upper bounding surface is often hiatal in nature due to sediment reworking, and may correspond to a subaerial unconformity (possibly equivalent to a sequence boundary) and an accommodation reversal surface (ARS). The entire package, including both clastic and coal facies, is termed here a drying-upwards succession (DU).

Another type of simple coal seam (Fig. 2) occurs when peat accumulates under a regime of increasing accommodation by the processes of paludification (Frenzel, 1983; Boron et al., 1987), leading to the formation of 'transgressive' style coal (Diessel, 1992). The base of the coal is referred to as a paludification surface $(\mathrm{PaS})$ which often rests on a well-developed soil horizon. The coal is characterized by one or more wetting-upward units, 


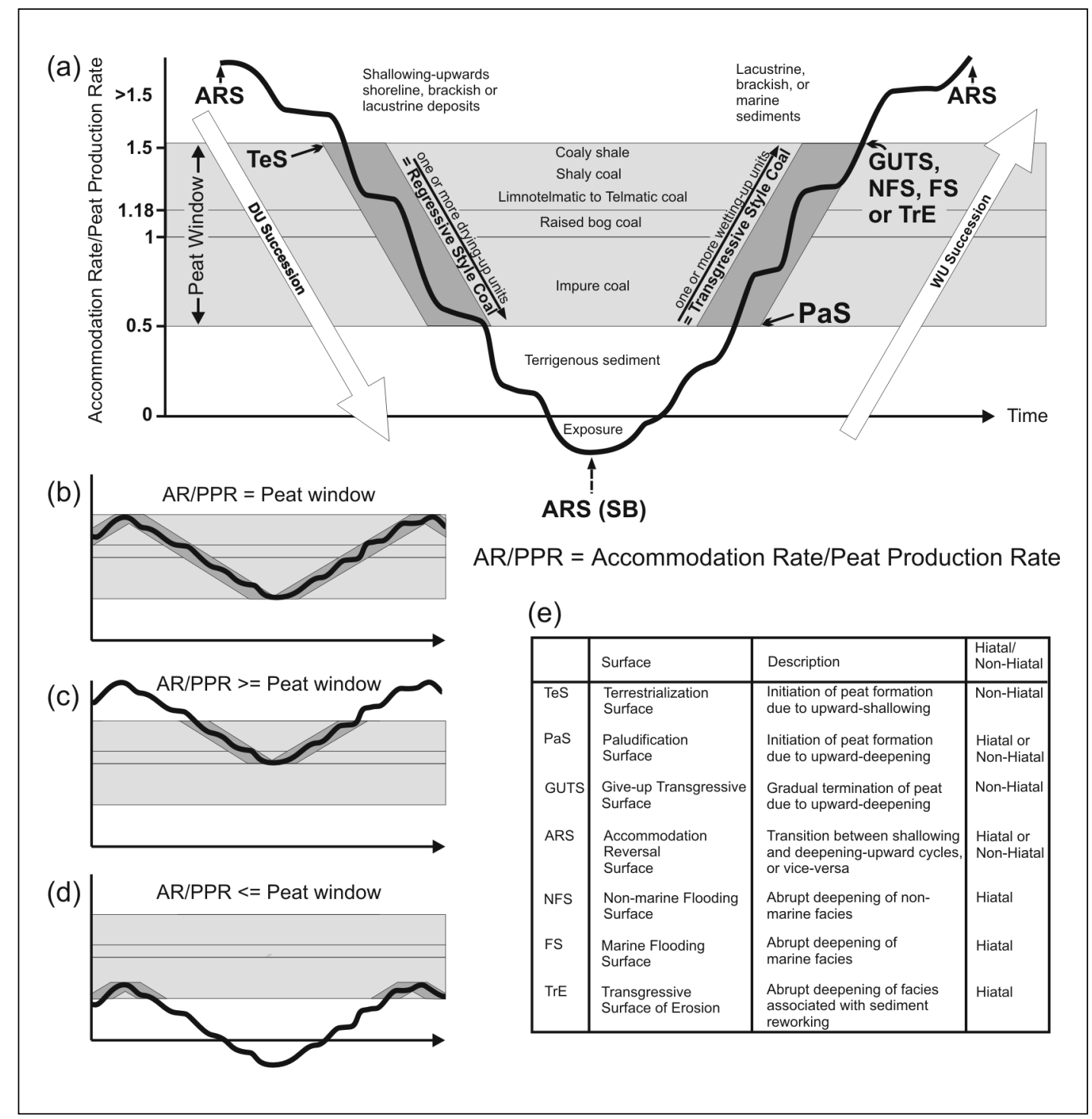

Fig. 2. Idealized curves show the relationship between paralic accommodation rate (AR) and peat production rate (PPR). The latter is assumed to remain relatively constant for an individual coal seam, and therefore accommodation rate is the key variable. The "peat window" occurs where AR/PPR falls between 0.5 and 1.5 (Bohacs and Suter, 1997). (a) If the amplitude of the AR/PPR curve is greater than the amplitude of the peat window, then both regressive and transgressive coals separated by hiatal surfaces may form. (b) If the AR/PPR curve lies entirely within the peat window, then a compound coal seam, with no internal hiatal surfaces, may develop. (c) If the AR/PPR curve lies mainly above the peat window, then the coals will be dominated by shaly, limnotelmatic, telmatic, or raised mire coals. (d) If the AR/PPR curve lies mainly below the peat window, then the coals will be impure and characterized by exposure surfaces. (e) Summary of sequence-stratigraphic surfaces associated with coal.

as shown by increased detrital-mineral content and other indicators of increasingly allochthonous dispersal of organic and inorganic peat components such as sporinite and inertodetrinite. If accommodation continues to increase beyond the maximum rate of peat production, peat formation will be replaced by lacustrine or flood basin deposits in the non-marine realm, or by marine deposits. The entire package, including both clastic and coal facies, is termed here a wetting-upwards succession (WU). The rate of accommodation increase is the main factor to determine at what point peat formation is replaced by clastic sedimentation (Diessel, 1998). If the increase in accommodation is gradual, peat will accumulate, albeit under less than optimal conditions, until the mire becomes flooded and a give-up transgressive surface (GUTS) caps the coal seam. Alternatively, if flooding of the peat is abrupt, then a non-marine flooding surface (NFS) or an estuarine, lagoonal or marine flooding surface (FS) forms the top of the seam. The distinction between a GUTS and an NFS hinges on the relative rate of accommodation increase; the former surface is gradational and non-hiatal, whereas the latter is abrupt, hiatal, and may coincide with an ARS. In view of the hydrologic connection between sea level and groundwater table in paralic coals, an FS correlates landwards to an NFS. The replacement of 
marine by non-marine flooding signifies a landward decline in the magnitude (and, to a lesser extent, rate) of the accommodation increase, so that the abrupt rise in relative sea level near the coast translates landward into a weaker rise of the connected groundwater table (Fig. 16 in Bohacs and Suter, 1997).

In reality, as opposed to the schematic in Figure 2, many coal seams show evidence of regional splitting and amalgamation and therefore cannot be described as simple transgressive or regressive coals. These compound coals, with or without internal hiatuses, have been formed over several relative sea level cycles so that they combine transgressive and/or regressive elements in one seam (Diessel, 1998). In the following sections, we examine the stratigraphy and internal characteristics of some of the Falher Member and Gates Formation coals, in order to determine the nature and correlatability of their accommodation signatures.

\section{Regional BACKGROUND}

The Gates Formation is the outcrop-equivalent of the subsurface Falher Member of the Spirit River Formation (Fort St. John Group) but formed closer to the orogen (Fig. 1). The Falher/Gates shorelines were wave-dominated with an east-west trend extending at least $200 \mathrm{~km}$ from the Rocky Mountain foothills of British Columbia into Alberta. Behind the shoreline was a broad, flat delta plain locally cut by streams flowing northwards from sources in the Cordillera. Original peat deposits were moderately thick $(10-60 \mathrm{~m})$ and widespread (Leckie, 1983).

In the area around the well-explored Deep Basin Elmworth gas field (Fig. 1; Masters, 1984), the Spirit River Formation is subdivided into three members (Fig. 3) on the basis of their dominant lithology (Stott, 1968, 1975, 1982).The Falher Member consists of several highly variable, aggradationally-stacked stratal packages (50-100 m thick) informally termed the Falher cycles by workers in the oil and gas industry. These packages are characterized by dominantly fine-grained non-marine sediments and coal in the south, grading laterally through shoreface sandstones and conglomerates to marine mudstones in the north (Fig. 3), and are capped by a regional flooding surface or ravinement surface. Although it is tempting to interpret the packages as parasequences, various workers (Arnott, 1993; Rouble and Walker, 1997; Casas and Walker, 1997) have identified multiple episodes of shoreline progradation with little evidence of relative sea level falls recorded, suggesting that at least some of the Falher cycles are better interpreted as parasequence sets.

Outcrop exposures of the co-eval Gates Formation (Lower Cretaceous Fort St. John Group) in the Foothills of northeastern British Columbia (McLearn, 1923; Stott, 1968, 1982; Leckie and Walker, 1982; Leckie, 1983, 1986a; Carmicheal, 1983, 1988) reveal a succession composed dominantly of channels filled with sandstone or conglomerate; and of coal and fine-grained nonmarine sediments which laterally grade into coarsening-upwards shallow marine shoreface units to the north (Fig. 3).

\section{Tectonics, Subsidence and Accommodation Patterns in the Falher Member and Gates Formation Areas}

During Upper Mannville times when the Falher Member and Gates Formation were being deposited, regional accommodation patterns in the WCSB were characterized by a progressive increase towards the west due to foreland basin subsidence (Price, 1981), and also towards the north due to subsidence of the isostatically depressed 'foredeep' of the Cretaceous Boreal Sea (Masters, 1979, 1984). The isopach map of total thickness of the Lower Mannville Group shown in Figure 4 (Cant and Abrahamson, 1994) provides a proxy for accommodation, and indicates that the strata do not conform to a simple pattern of cratonward thinning, but show thickness irregularities that can be used to define three north-south trending physiographic zones (Cant and Abrahamson, 1996). These zones suggest that the main controls on deposition are Devonian salt collapse to the east, erosional basement topography in the central basin, and flexural subsidence to the west of the Fox Creek Escarpment, a westward-facing erosional slope formed on the basement unconformity (McLean, 1977). These underlying controls probably continued to exert an influence on stratal thickness throughout Upper Mannville Group times as well, and it is on the basis of this assumption that we define areas of low, intermediate, high and very high accommodation (Fig. 4). The Falher Member is therefore assumed to have been deposited in a high accommodation setting. Mannville Group isopach data are not available for the Gates Formation study area, but because it is situated west of the thrust belt it most likely formed in a very high accommodation setting.

In addition to flexural subsidence, sedimentation patterns in both the Gates Formation and Falher Member were probably also influenced by the former Peace River Arch (Douglas, 1970; Leckie, 1986b; Cant, 1988; Barclay et al., 1990; O'Connell et al., 1990) (Fig.1). The maximum southerly (transgressive) and northerly (regressive) limits of the Falher cycles (Fig. 5) occur within an east-west trending zone, 30-40 km wide (Leckie, 1986a). This aggradational pattern of thick, stacked shoreface cycles is characteristic of a high to very high accommodation setting, and may be partly influenced by a hinge line in the area of Bullmoose Mountain, associated with tectonic thrusting and loading superimposed on the trend of the Peace River Arch (Fig. 1). Further evidence for this underlying structural control is shown by sediment distribution patterns, with marine strata thickening to the north of this location and non-marine strata thickening to the south (Fig. 3). Pate (1988) regards the aggradational stacking pattern of the Falher shorefaces (Leckie, 1986a) to be partly constrained by the position of a basement high (from Twp 69-72, Rng 8-14W6). Apparently, this feature was more structurally stable than the surrounding regions, and thus prevented southward migration of the Clearwater sea. 


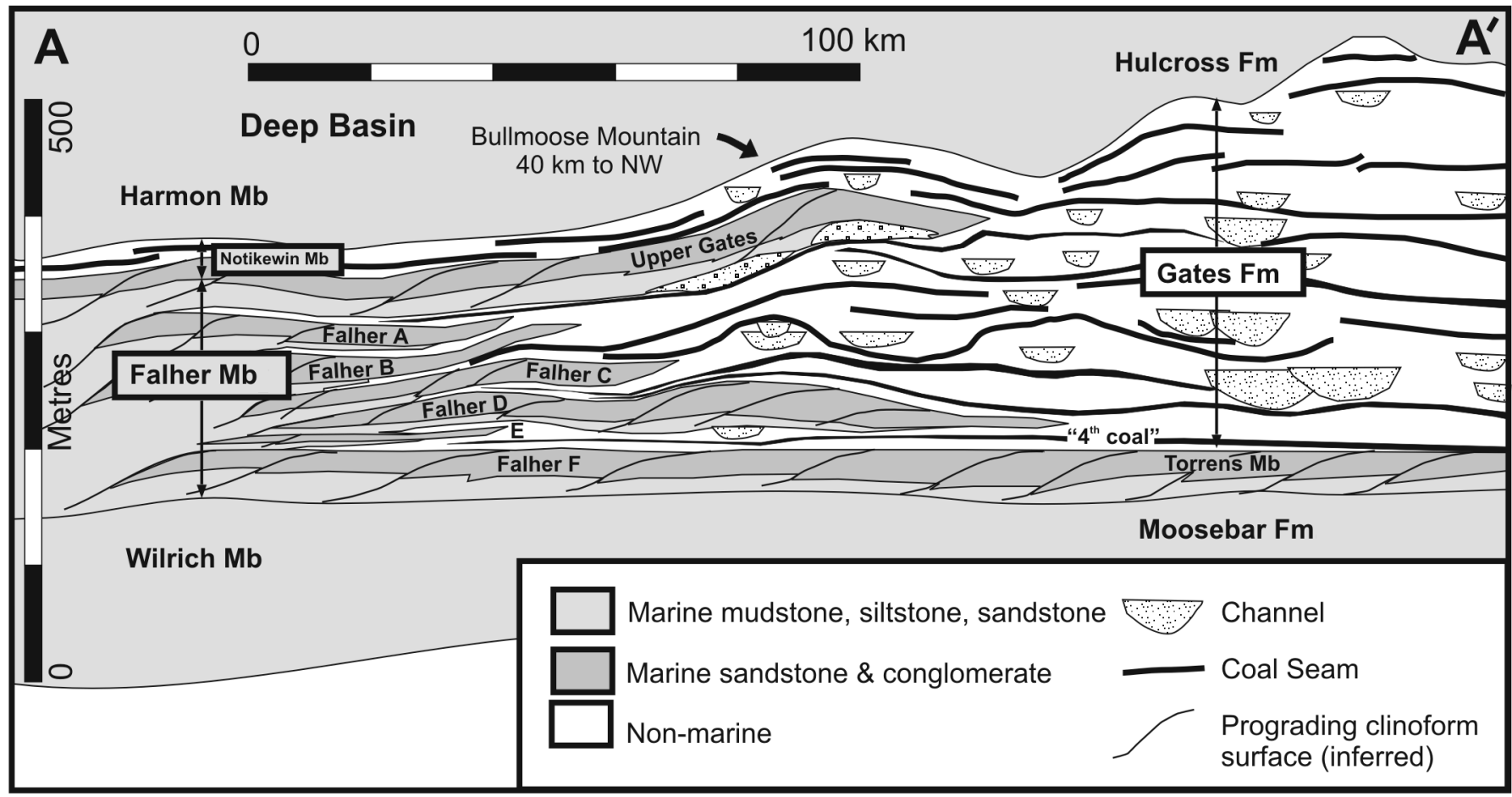

Fig. 3. Regional cross-section of the Gates Formation and Falher Member (modifed from Carmichael, 1988). Location is shown in Figure 4. The southern part of the section is based on core and outcrop data in Carmichael (1983). The northern part of the section is based on data in Leckie (1986a). The Gates Formation and Falher Member are time equivalent, and generally refer to the non-marine component and marine component of the stratigraphy, respectively.

\section{Previous Views on the Sequence Stratigraphic Significance of the FalHer and Gates Coals}

There is no existing sequence stratigraphic interpretation of the Gates Formation, and it has never been internally correlated to the Falher Member. However, detailed investigations of the Falher Member (Leckie and Walker, 1982; Cant, 1983, 1984; Smith et al., 1984; Jackson, 1984; Arnott, 1993; Rouble and Walker, 1997; Casas and Walker, 1997) show evidence of a strong relative sea level cyclicity, and therefore it is reasonable to expect that there may be some expression of accommodation cyclicity in the Gates non-marine strata (Fig. 3).

The Falher cycles were originally interpreted as transgressive-regressive, marine to non-marine successions (van Hinte, 1976; Kauffman, 1977; Masters, 1984; Ryer, 1984; Leckie, 1986a ; Cant and Abrahamson, 1996), and the upper boundaries of the cycles were not clearly defined. Various authors propose contrasting views on the sequence stratigraphic nature of the Falher cycles, as well as the significance of the non-marine coal bearing strata. Correlations by Cant $(1983,1984)$ placed the coals at the top of the regressive cycles, immediately below marine flooding surfaces. However in his later study, Cant (1995) argues against contemporaneous shoreline regression and non-marine aggradation, and suggests instead that the widespread, coal-bearing muddy non-marine strata represent initial transgressive deposits, which probably developed landward of a transgressive barrier complex. The non-marine deposits were then capped by a transgressive surface of erosion. Along similar lines, Demarest and Kraft (1987) suggest that the non-marine deposits were capped by transgressive ravinement surfaces and underlain by sequence boundaries (Fig. 6a), and that the coals are therefore transgressive. In contrast, Arnott (1993) indicates that the non-marine deposits and coals capping the Falher D cycle represent the culmination of shoreface progradation, and are overlain by a regional flooding surface (Fig. 6b). Rouble and Walker (1997) and Casas and Walker (1997) interpret the coalbearing non-marine sediments of the Falher A-D cycles to have aggraded behind shorefaces during highstand conditions, contemporaneous with shoreface progradation (Figs. 6c, d), which suggests that the coals are regressive in origin. They divide the flooding surface above the non-marine deposits into a marine flooding surface (downdip), a composite marine flooding surface/regressive surface of erosion (mid-section), and a nonmarine flooding surface (updip). They do not recognize any sequence boundaries per se, although they do identify a possible candidate below a $20 \mathrm{~m}$ deep channel at the top of Falher B.

In summary, there is a detailed stratigraphic history of the Falher cycles with a range of interpretations. In particular, the coaly strata have been placed in both the transgressive and regressive units. In our opinion the coal deposits are one key to interpreting the stratigraphy, and in the following sections we outline our approach to using the style of coal development as a tool for improved stratigraphic interpretation and correlation. 


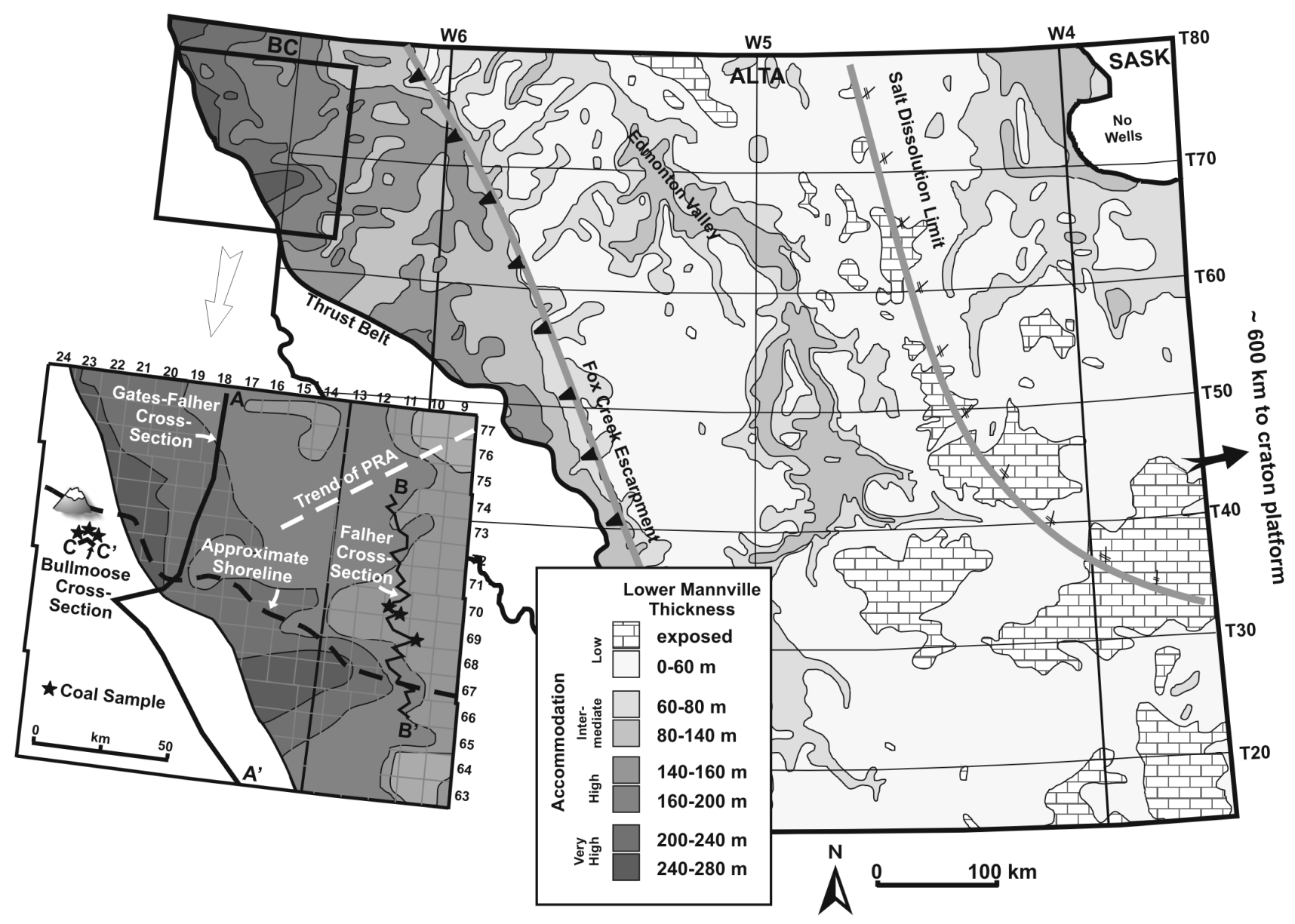

Fig. 4. Map of Alberta Foreland Basin, Canada, showing the location of the study area. The isopach contours represent thickness of the Lower Mannville Group (modified from Cant \& Abrahamson, 1994 and after Diessel et al., 2000) which can be used as a proxy for regional subsidence and accommodation patterns. This map suggests that the study area lies within a region of high to very high accommodation. The inset map shows cross-section locations. The regional Gates Formation cross-section A-A' (Fig. 3) integrates subsurface data in the north with oucrop data in the south. The regional Falher Member cross-section B-B' (Fig. 7) runs approximately parallel to A-A'. The detailed Gates Formation cross-section C-C' (Fig. 9) from Bullmoose Mountain area is located approximately $40 \mathrm{~km}$ northwest of section A-A'. The white dashed line shows approximate position of the Peace River Arch (PRA). Location of wells from which coals samples have been obtained is indicated by black stars.

\section{STRATIGRAPHY}

In order to establish a stratigraphic framework and better understand the depositional context of the coal-bearing nonmarine sediments, stratigraphic cross-sections were constructed and correlated from the Elmworth and Bullmoose Mountain areas using subsurface wireline log and core data (Fig. 4 inset). Additional insights into the paleogeography and regional stratigraphy were obtained from published information (Leckie and Walker, 1982; Cant, 1983, 1984, 1995; Leckie, 1986a, 1986b; Demarest and Kraft, 1987; Carmichael, 1988; Cant and Stockmal, 1993; Arnott, 1993; Cant and Abrahamson, 1996; Rouble and Walker, 1997; Casas and Walker, 1997).

\section{Falher Member Stratigraphy at Elmworth}

Our investigation of Falher Member coal-bearing strata is based on the south-north cross section $\mathrm{B}-\mathrm{B}^{\prime}$ illustrated in
Figure 7. The datum used is the transgressive erosion surface at the base of the Notikewin Member. The cross-section shows a number of northward progradational shoreface cycles. Major bounding surfaces (flooding surfaces or modified transgressive erosion surfaces) are highlighted by dashed grey lines. Typically, they separate non-marine strata below from marine strata or transgressive lag deposits above. In order to better view the geometry of the non-marine packages, a Wheeler-type diagram has been constructed using the bounding surfaces between each cycle as a horizontal datum surface (Fig. 8). This diagram was constructed using only those wells from Figure 7 with core control, and therefore only the Falher A-C cycles are illustrated. A description of the sedimentary facies is given in Table 1.

Nine regionally correlatable cycles are identified in Figure 7 (highlighted by arrows). The bottom three (unnamed) cycles are within the Wilrich Member. Each consists of a number of 


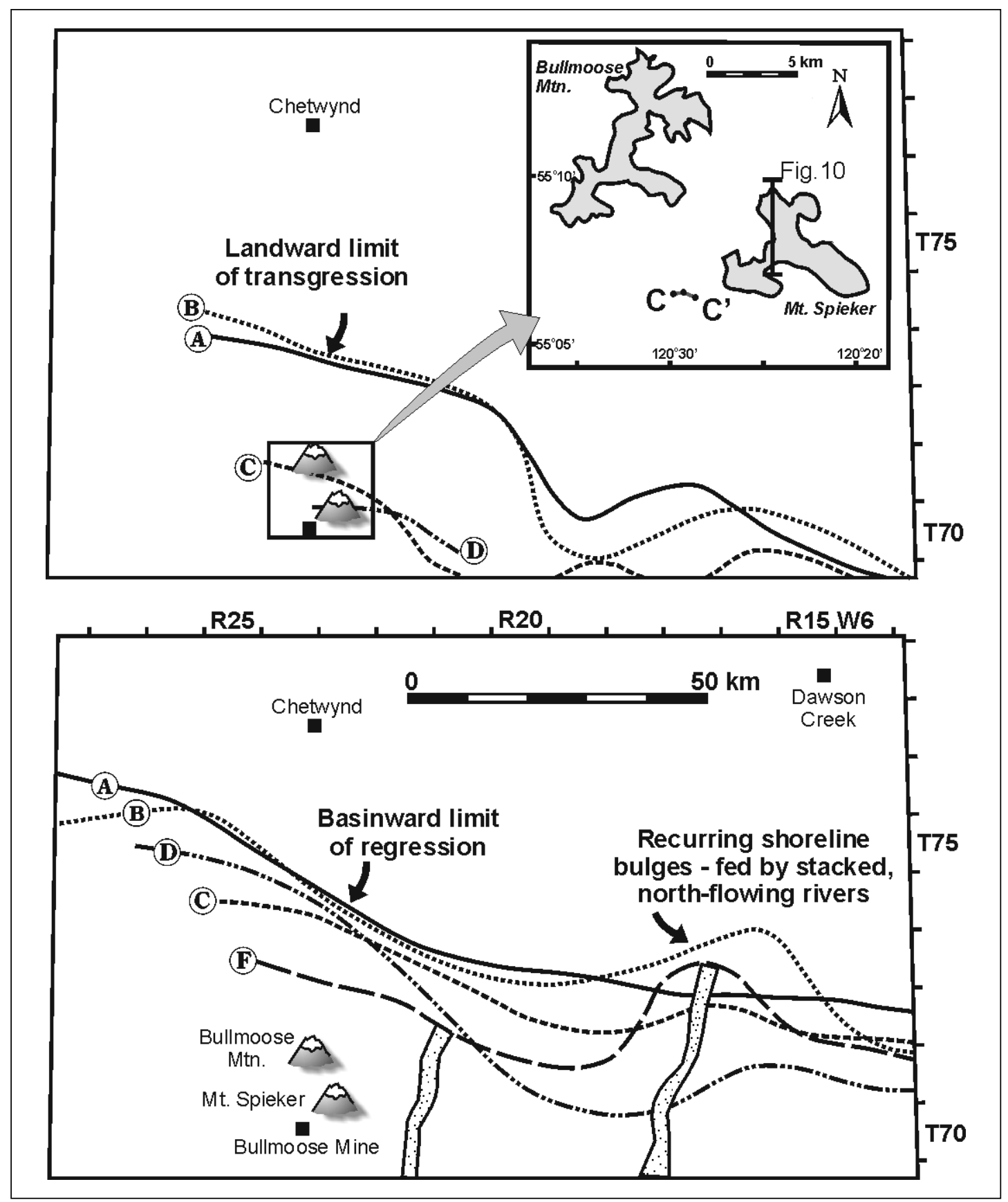

Fig. 5. Overlays of the regressive (lower), and transgressive (upper) limits of Gates Formation cycles (after Leckie, 1986a). Letters $A$ to $F$ refer to the equivalent Falher shorefaces. Note that the transgressive limit of Falher $C$ and D occurs just to the north of the Bullmoose Mine area. The transgressive limit of Falher F occurs south of Calgary, over $600 \mathrm{~km}$ to the southeast of the study area (McLean, 1982; Taylor and Walker, 1984; Leckie, 1986a).

coarsening-upwards units which are generally gradational rather than sharp-based, and are interpreted as a set of basinward-stepping progradational distal shoreface units. Coal-bearing, nonmarine mudstones cap only one of the Wilrich cycles (south of Twp 68); they were either eroded or did not develop above the other cycles, at least in the study area. Falher cycles A through F (indicated by arrows) are each capped by a unit of non-marine, coal-bearing strata of variable lateral extent. Falher F merges with Falher E in the area of Twp 71, and comprises at least three stacked shoreface units, with the uppermost one capped by a thin $(<1 \mathrm{~m})$, widespread coal which either dies out or is eroded basinward in the area of Twp 73. This coal thickens landward.

\section{FaLHer C}

The progradational shoreface unit in Falher C (Fig. 7) is erosionally truncated by a wide, fining-upwards channel fill in the area of Twp 70-71. This agrees with the correlations suggested by Casas and Walker (1997; our Fig. 6d), who interpret a 


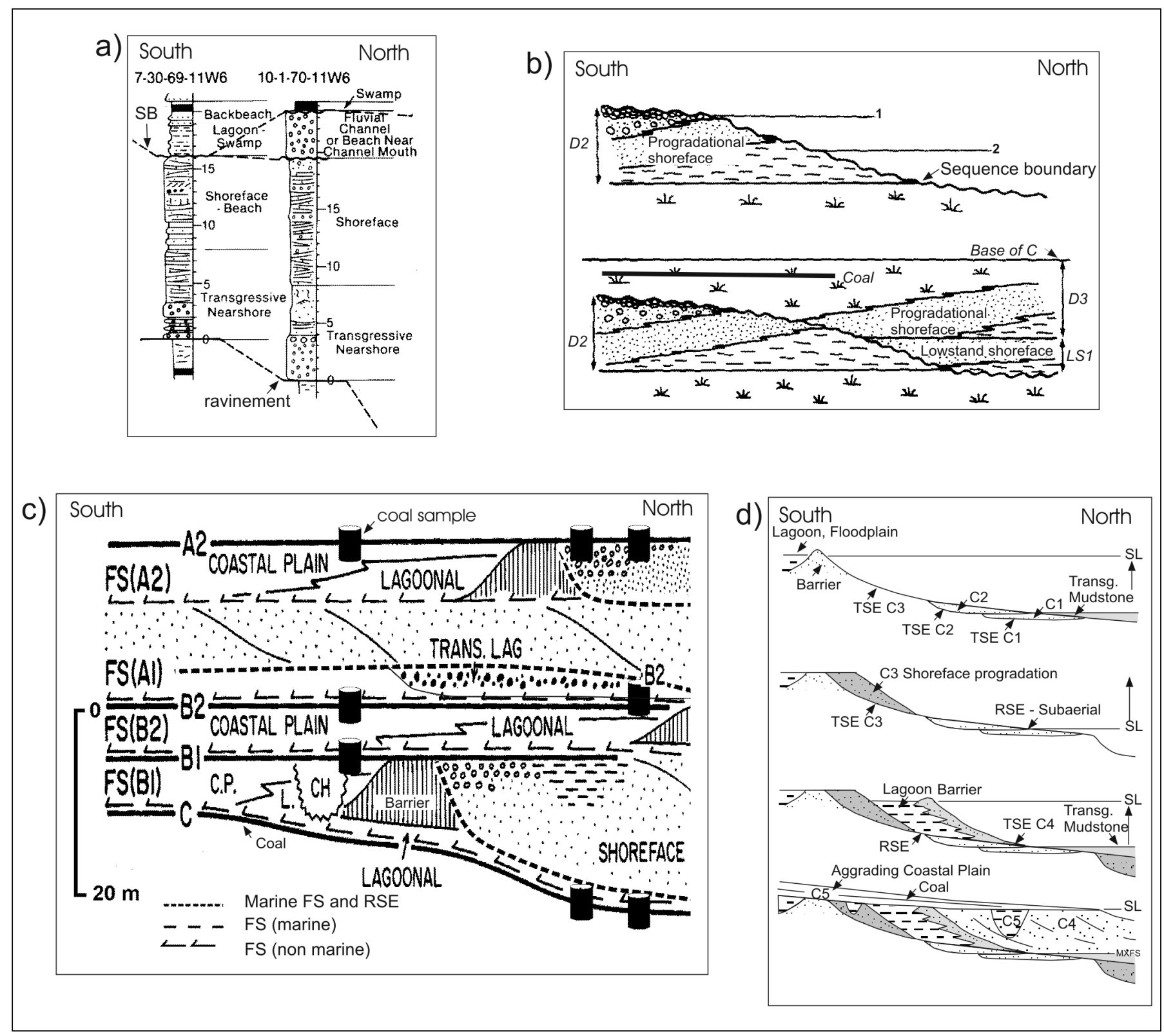

Fig. 6. a) Reinterpretation of Falher A by Demarest and Kraft (1987). They suggest that the bottom dashed line at $0 \mathrm{~m}$ is a ravinement surface within a transgressive succession and the upper dashed line is an unconformity surface over which subsequent transgression occurred (after Cant, 1984). b) Depositional model for Falher D proposed by Arnott (1993). In the top diagram, the D2 shoreline progrades northward during SL1. Following a fall in relative sea level (RSL), a regressive surface of erosion (sequence boundary) is created. In the bottom diagram, lowstand sediments (LS1) are deposited above the sequence boundary. Following a rise in RSL, the D3 shoreline and backbarrier non-marine sediments are deposited. c) Alternative interpretation of depositional environments of Falher A and B (from Rouble and Walker, 1997). Each cycle is interpreted to have formed over two episodes of transgression and regression. d) Similarly, Casas and Walker (1997) suggest that Falher C also formed over two episodes of transgression and regression.

north-south distributary channel as well as two smaller, backstepping shorefaces at the base of the cycle. The landward limit of transgression occurs at Twp 66. The non-marine package overlying the shoreface units extends basinward beyond the limits of the study area (Twp 74), and merges landward with the non-marine packages of both Falher D and Falher B (Fig. 7). It contains at least three thin $(0.5-2 \mathrm{~m})$, moderately widespread coals, one of which has been sampled in two places for detailed coal analysis (6-7-70-11W6, 11-4-70-11W6). In some places the lowermost coal rests directly above the shoreface sandstone (Fig. 7), but elsewhere core evidence shows that the coals are generally underlain by coarseningupward brackish bay fill deposits, with evidence of pedogenesis near the top (Table 1). Either lacustrine or brackish bay sediments overlie the coals. Minor seam splits are evident, with interseam strata from 1 to $10 \mathrm{~m}$ thick. 


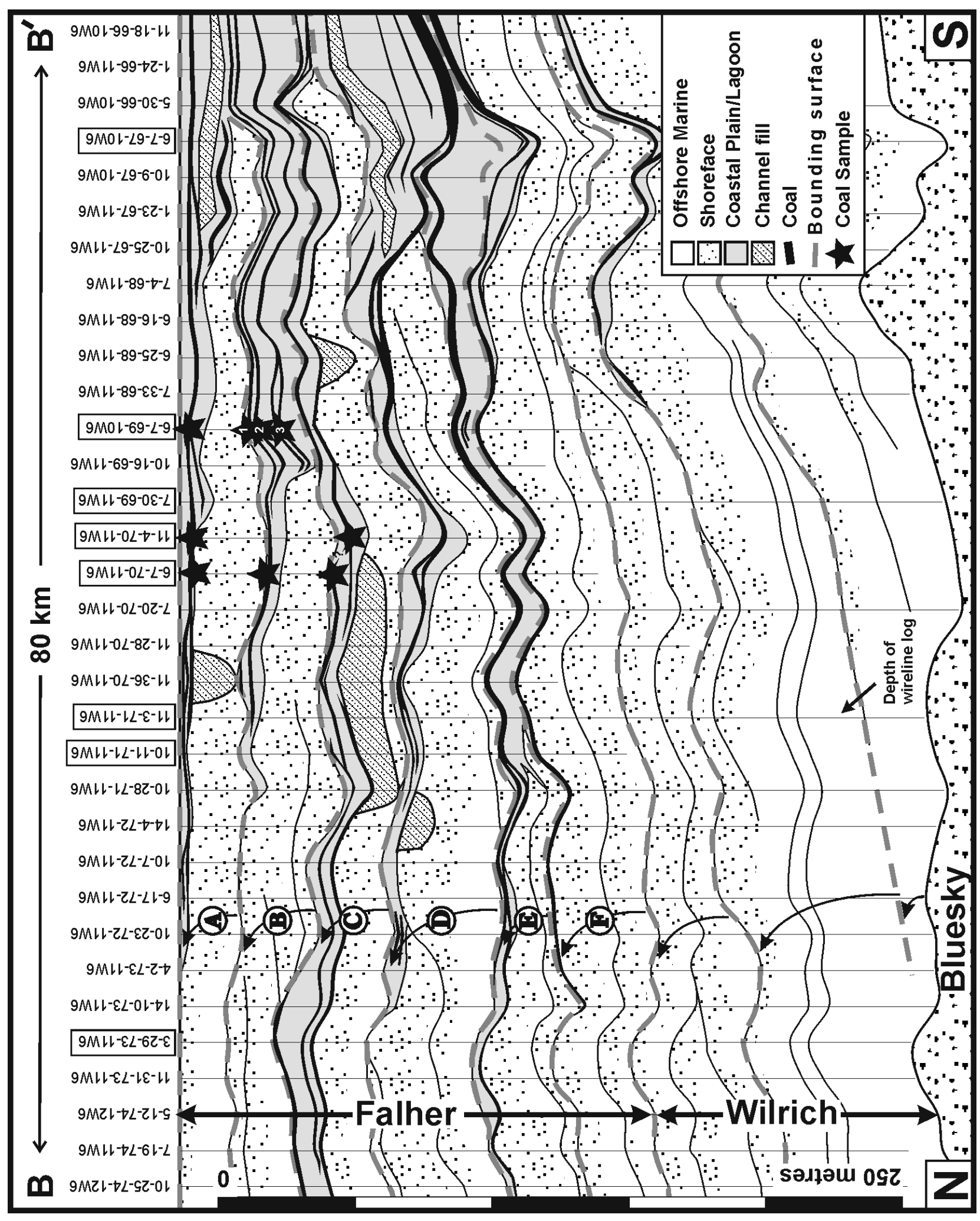

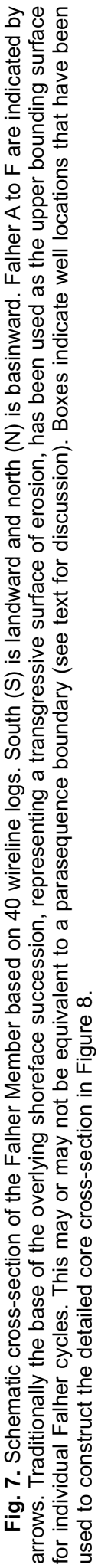




\section{FALher B}

Falher B consists of at least four shingled shoreface units, with a maximum landward limit of transgression at Twp 69 (Fig. 7). These units correspond with the shingled B1 and B2 shorefaces proposed by Rouble and Walker (1997) and shown in Figure 6c. The overlying non-marine mudstones terminate basinward at Twp 72, due to erosion by the overlying surface, and merge with Falher $\mathrm{C}$ and Falher A non-marine units in a landward direction. The Falher B mudstone unit contains at least four (approximately $1 \mathrm{~m}$ thick) stacked coal seams, sampled in two locations (6-7-70-11W6, 6-7-69-10W6). No coals occur directly above shoreface strata (Fig. 7), but instead are typically underlain by marsh, bay fill, or floodplain deposits (Table 1) from 1 to $10 \mathrm{~m}$ thick.

\section{FALHER A}

On the basis of well log signatures alone we are only able to distinguish one shoreface unit in Falher A (Fig. 7), although the core-based study of Rouble and Walker (1997) indicates that this package can be subdivided into two shoreface units, separated by a transgressive marine package north of Twp 72. The landward limit of transgression occurs at Twp 66. A possible fine-grained channel fill truncating the entire shoreface unit at 11-36-70-11W6 may correlate to the south with a thinner, sandier channel fill in Twp 67-66. The overlying non-marine unit thickens landward from $<1 \mathrm{~m}$ (Twp 73) to approximately $15 \mathrm{~m}$ (Twp 66), where it merges with the Falher B non-marine mudstones. A thin, widespread coal $(<0.5$ to $1.5 \mathrm{~m}$ thick) within the non-marine unit locally splits and rejoins, and has been sampled for analysis at three separate locations (6-7-70-11W6, 11-4-70-11W6, 6-7-69-10W6). In the northern (i.e. basinward) part of the cross-section, the bottom coal overlies the marine shoreface strata, but southward the seam is more typically underlain by bay fill, floodplain, or lacustrine strata (Fig. 7).

In summary, the cross-sections of Falher cyles A-E in Figures 7 and 8 show some general trends in stratal geometry. Each consists of a marine component that is overlain by, and/or laterally equivalent to, a non-marine succession. The marine succession consists of at least one, but usually several, shoreface units that are either stacked or more commonly shingled, indicating progradation interrupted by flooding. The shorefaces can either be sharp- or gradationally-based, and in many cases an individual shoreface changes from sharp-based to gradational in a basinward direction.

The stratal patterns associated with the coal-bearing, nonmarine parts of the Falher cycles are more difficult to interpret, because it is seldom clear whether the basinward limit of the non-marine units is due to depositional pinch-out or to erosional truncation by the overlying bounding surface (i.e. the flooding surface or erosion surface associated with the overlying cycle). All of the non-marine units display some similarities; they are wedge shaped, thicken landward (from $<1 \mathrm{~m}$ to $10-35 \mathrm{~m}$ thickness), and merge landward. They all contain at least one thin, widespread coal seam. Many of these coal seams can be correlated updip for at least $60 \mathrm{~km}$. They are generally $<0.5 \mathrm{~m}$ to
$2.0 \mathrm{~m}$ thick, and are characterized by minor splits and rejoins, with the splits occurring mainly in a basinward direction. Maximum seam thickness of landward-merged seams is about $5 \mathrm{~m}$. Individual coal seams do not thicken or thin significantly, and there are typically more coal seams landward than basinward. This latter pattern may be due to erosion of the coal seams by the overlying unconformity. The coals are typically underlain by shoreface, brackish bay fill, or floodplain deposits, and are overlain by brackish bay-fill or lagoonal/lacustrine deposits.

\section{Gates Formation Stratigraphy}

Cross-section $\mathrm{C}-\mathrm{C}^{\prime}$ in Figure 9 has been constructed from three coal company borehole cores and wireline logs (gamma and density) from the Bullmoose Mine, located to the southeast of Bullmoose Mountain (Fig. 5). Five major coal seams are present, locally termed the A seam to E seam, from which outcrop samples have been obtained and analyzed. The Gates Formation has also been investigated in outcrop at Mt. Spieker (Fig. 10) (Leckie and Walker, 1982). Sedimentary facies recognized in the Gates Formation in this area are summarized in Table 1.

The Gates Formation at Bullmoose Mine spans an 80 to $85 \mathrm{~m}$ thick interval of non-marine strata that is laterally equivalent to several of the Falher shoreface cycles. It displays rhythmic stratal patterns that are interpreted as drying- and wetting-upwards successions (Fig. 9). Stratal packages (4-20 m thick) consisting of coarsening-upwards lacustrine, floodplain, crevasse splay, fluvial channel, marsh and coal deposits are interpreted as non-marine drying-upwards successions (DU). Stratal packages (2-8 m thick) consisting of coal, marsh, and fining-upwards lacustrine deposits are intrepreted as nonmarine wetting-upwards successions (WU). If it is assumed that a full non-marine accommodation cycle consists of a WU followed by a DU (analogous to a marine transgressive-regressive cycle), then eleven cycles or partial cycles are present (Fig. 9). Coal seams occur at the turn-around point between dryingupwards and wetting-upwards conditions, with the exact position of the bounding surface (an ARS) determined by analysis of the accommodation signature within the coal seam itself (Diessel et al., 2000).

\section{Coal Analysis}

The correlations discussed in the previous section show that coals can be used as gross lithological markers to connect marine dominated strata to non-marine dominated strata. However, this type of stratigraphic correlation provides little insight regarding the position of the coals within the overall accommodation cycle. The marine Falher cycles are subdivided on the basis of marine flooding surfaces (and transgressive and regressive surfaces of erosion; Rouble and Walker, 1997). How these surfaces translate into non-marine strata, and how they relate to the development of coal seams, cannot be determined from stratigraphic correlation alone, particularly when using only wireline logs. 
Table 1. Sedimentary Facies of the Gates Formation and Falher Members. Based on our observations from core, and from published sources (Leckie and Walker, 1982; Rouble, 1994; Rouble and Walker, 1997; Casas and Walker, 1997).

\begin{tabular}{|c|c|c|}
\hline Facies & Description & Interpretation \\
\hline $\mathrm{CL}$ & Light and dark banded coal with shale partings ( $<1$ to $150 \mathrm{~cm}$ thick). & Peat \\
\hline MR & Coaly shale, abundant plant debris, with root traces. & Marsh \\
\hline FP & $\begin{array}{l}\text { Carbonaceous siltstone with thin, interbedded rippled sandstone. Mild } \\
\text { pedogenesis. Coal stringers, root traces, plant fragments and convolute } \\
\text { bedding locally abundant. }\end{array}$ & Floodplain \\
\hline $\mathrm{LN}$ & $\begin{array}{l}\text { Dark carbonacous shale, massive to laminated, with lag of organic debris, } \\
\text { and interbeds of coal, siltstone and sandstone. Local siderite, wood } \\
\text { fragments, soft sediment deformation. Coarsens upwards to ripple- or } \\
\text { parallel-laminated muddy sandstone. Rare bioturbation, may become rooted } \\
\text { and mottled upwards. }\end{array}$ & $\begin{array}{l}\text { Lacustrine or } \\
\text { lagoon, with initia } \\
\text { flooding phase anc } \\
\text { upwards shoaling }\end{array}$ \\
\hline CS & $\begin{array}{l}\text { One or more sharp-based, fining-upwards units of siltstone \& fine-grained, } \\
\text { ripple to planar-laminated sandstone }(10-50 \mathrm{~cm} \text { thick), overlain by } \\
\text { bioturbated mudstone }(1-5 \mathrm{~cm} \text { thick). Glossifungites. }\end{array}$ & Crevasse splay \\
\hline $\mathrm{BF}$ & $\begin{array}{l}\text { Sharp-based, coarsening upwards unit, } 2-8 \mathrm{~m} \text { thick, } 20 \mathrm{~km} \text { wide. Mudstone } \\
\text { with syneresis cracks, organic debris, siderite and pyrite nodules, bivalves, } \\
\text { and abundant Helminthopsis and Chondrites. Grades upwards into } \\
\text { interbedded sandstone with planar- and ripple -lamination, moderate } \\
\text { bioturbation (Planolites, Rosselia, Teichichnus, Palaeophycus, Asterosoma). } \\
\text { Top contact rooted or overlain by coal. }\end{array}$ & $\begin{array}{l}\text { Brackish bay fill } \\
\text { with upwards } \\
\text { increasing marine } \\
\text { influence }\end{array}$ \\
\hline $\mathrm{CH}$ & $\begin{array}{l}\text { Sharp-based, conglomeratic to M- and F-grained sandstone, upward-fining, } \\
\text { up to } 10 \mathrm{~m} \text { thick. Structures include cross-bedding, parallel bedding and } \\
\text { ripples, roots near top. May contain a basal lag of pebbles, mud- and coal- } \\
\text { intraclasts. }\end{array}$ & Channel \\
\hline B & $\begin{array}{l}\text { F-grained sandstone with massive to low-angle parallel bedding, plant } \\
\text { debris. Intense bioturbation (Macaronichnus segregatis) } 2-4 \mathrm{~m} \text { below top } \\
\text { surface. Rooted upper surface. }\end{array}$ & Beach \\
\hline US & $\begin{array}{l}\text { F-grained sandstone with planar-tabular and trough cross-bedding, sets up to } \\
40 \mathrm{~cm} \text { thick. }\end{array}$ & Upper shoreface \\
\hline $\mathrm{PZ}$ & VF-grained sandstone, with Paleophycus bioturbation zone. & Middle shoreface \\
\hline LS & VF-grained sandstone with amalgamated HCS. & Lower shoreface \\
\hline OS & $\begin{array}{l}\text { Shale with thin interbeds of VF-grained sandstone with HCS and wave } \\
\text { rippes. Moderate to intense bioturbation. }\end{array}$ & Offshore \\
\hline TL & Coarse conglomerate or coarse to granular sandstone. & Transgressive lag \\
\hline
\end{tabular}

Analysis of coal-petrographic constituents and their derived parameters was carried out following the methodology described in Diessel et al. (2000). Samples were taken on the basis of the lithotype distribution in the coal seams, at a spacing of between 2 and $5 \mathrm{~cm}$. All samples were crushed to less than $2 \mathrm{~mm}$ diameter, and a representative portion of each was set in epoxy resin as raw coal. After curing, the samples were cut and polished according to standard methods for microscopic analysis in incident light. Telovitrinite reflectance (\%Rrt) was measured in oil immersion according to Australian Standard 2486-1989, and telovitrinite fluorescence intensity (I $650 \mathrm{wt}$ ) was measured in water immersion at a wavelength 


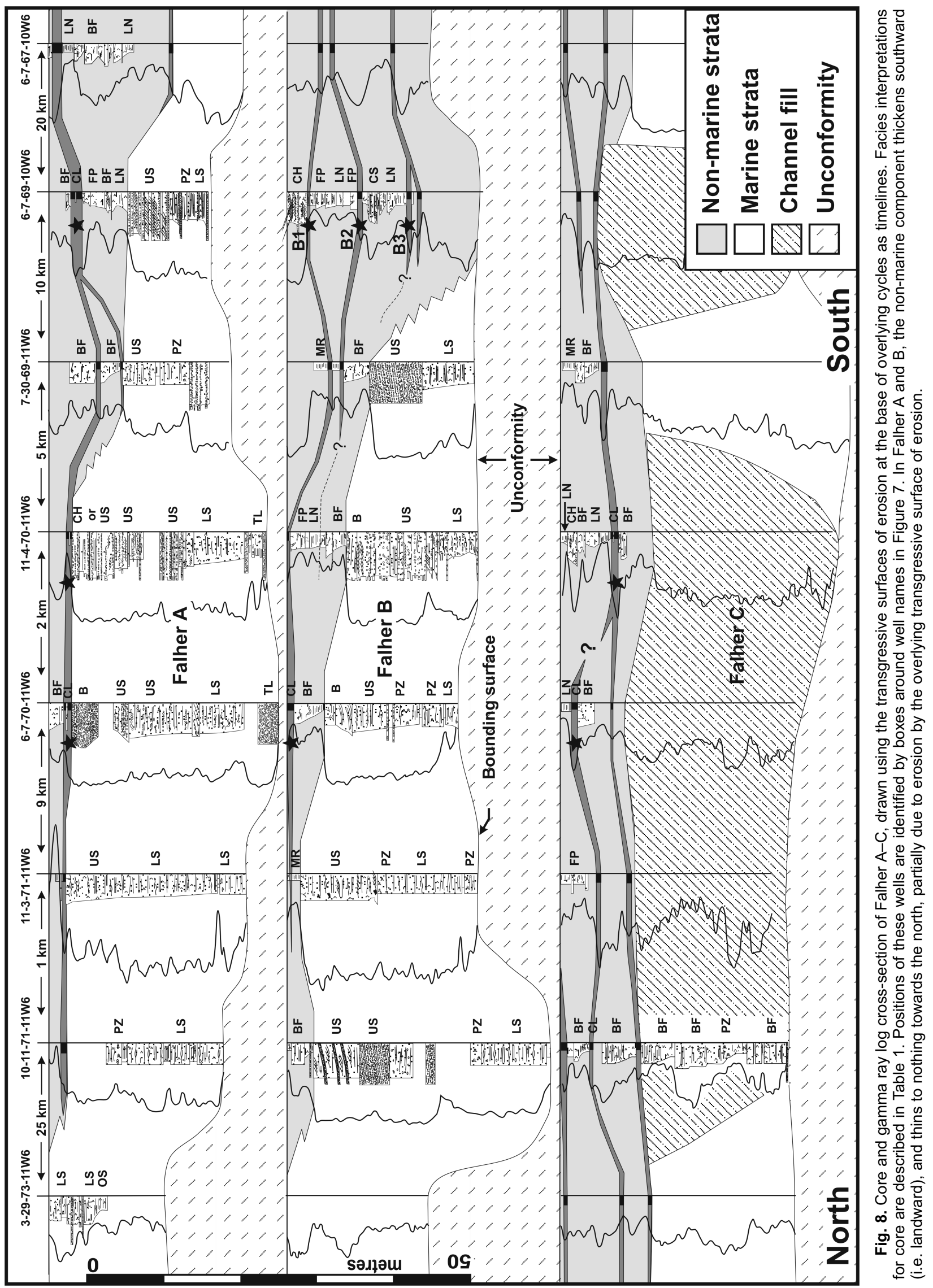




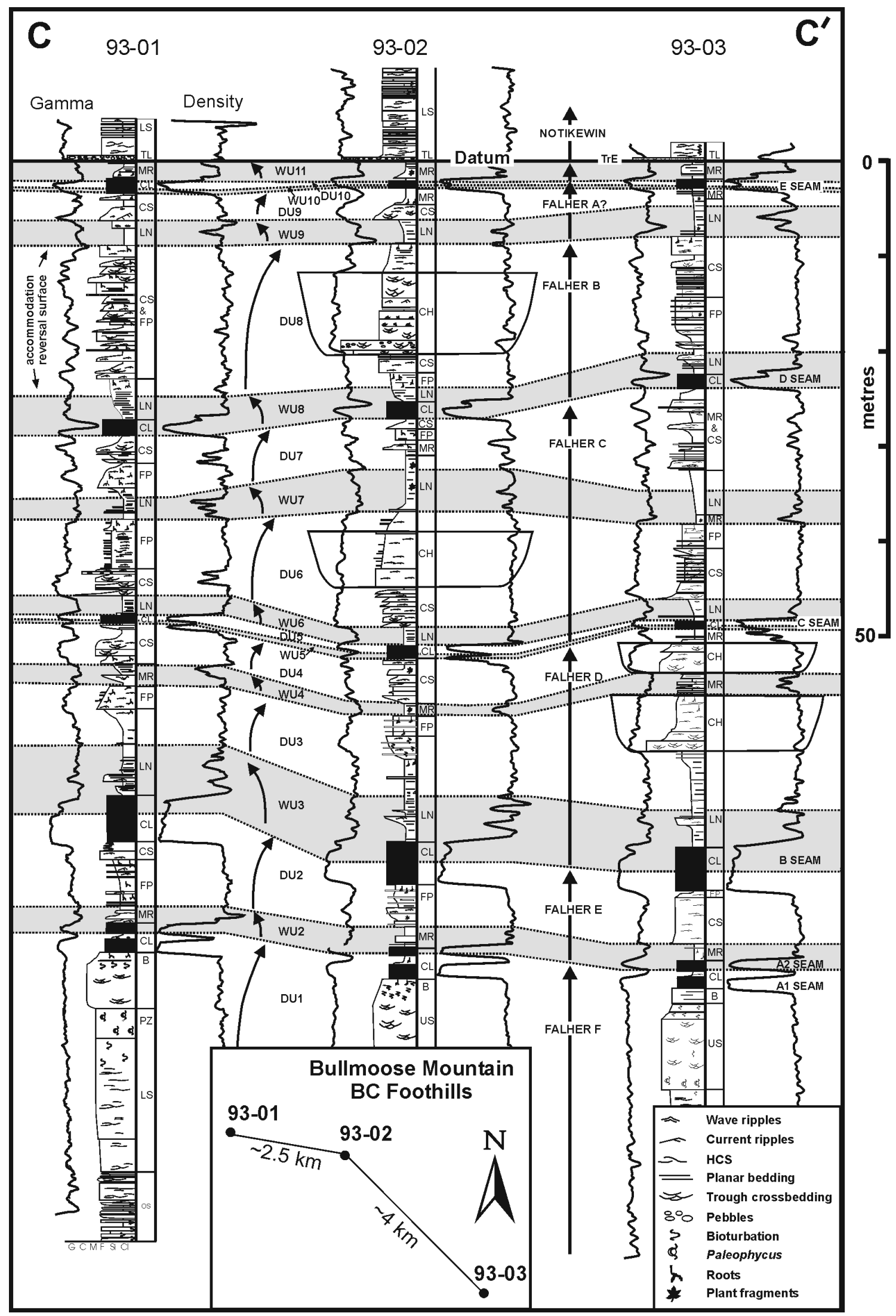

Fig. 9. Cross-section of the non-marine sediments of the Gates Formation from the Bullmoose Mine area near Bullmoose Mountain, B.C. foothills, based on logged core, gamma and density logs. Eleven cycles or partial cycles are recognized, with each cycle comprising a drying-upwards succession (DU) and a wetting-upwards succession (WU). These non-marine cycles are correlated to the subsurface Falher transgressive-regressive cycles (as suggested on the RHS of the figure - see text for discussion). Refer to Figure 2 for definitions of abbreviations. 


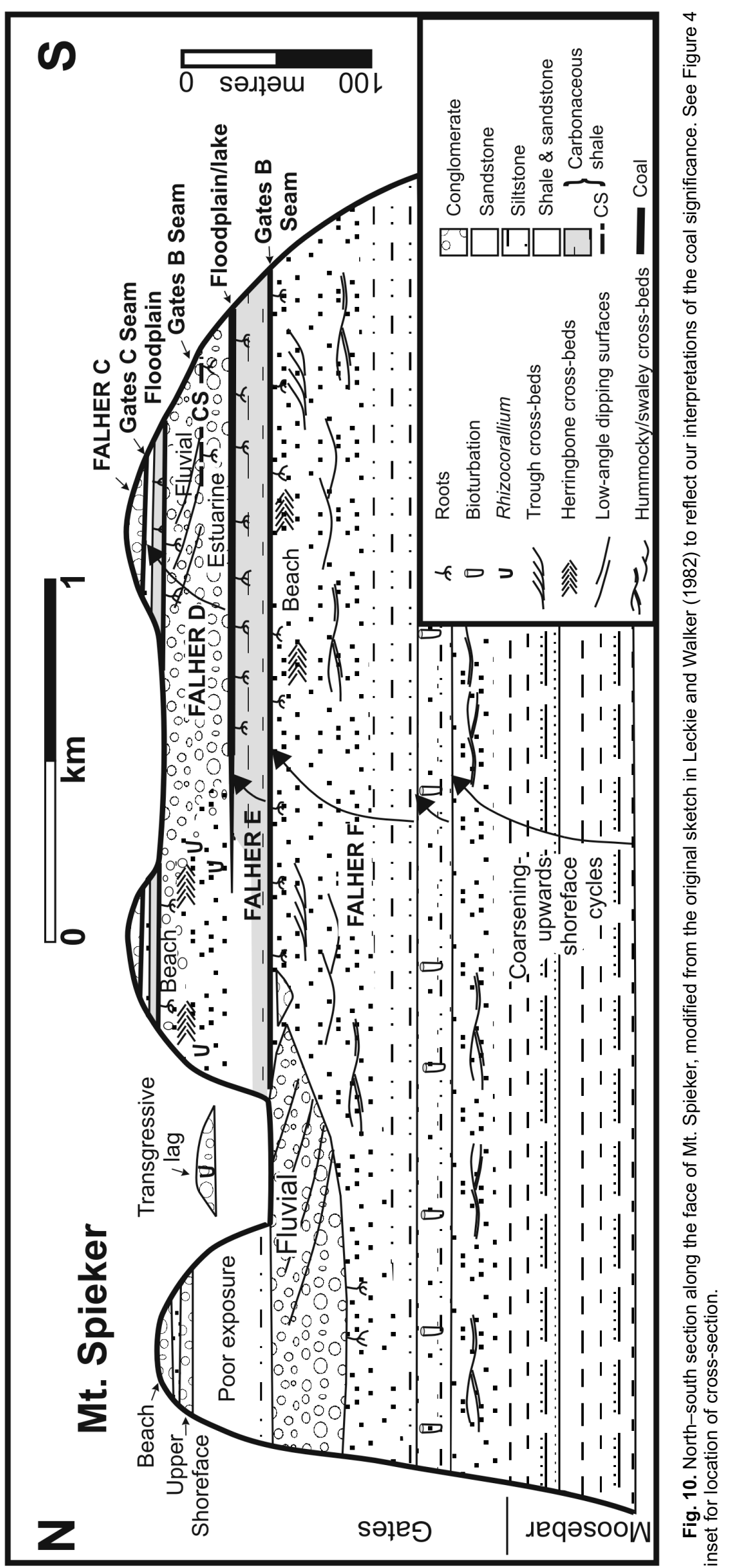



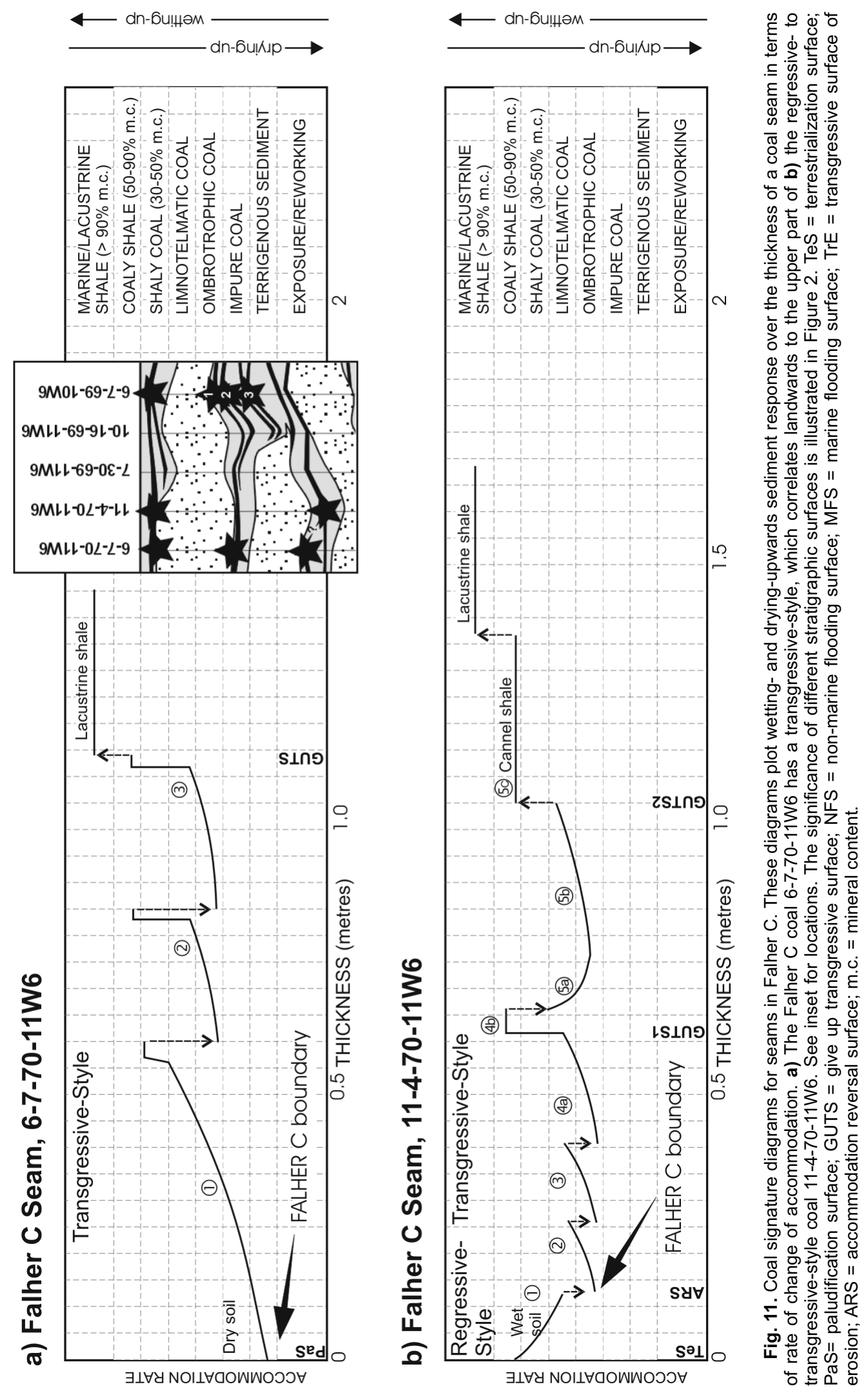

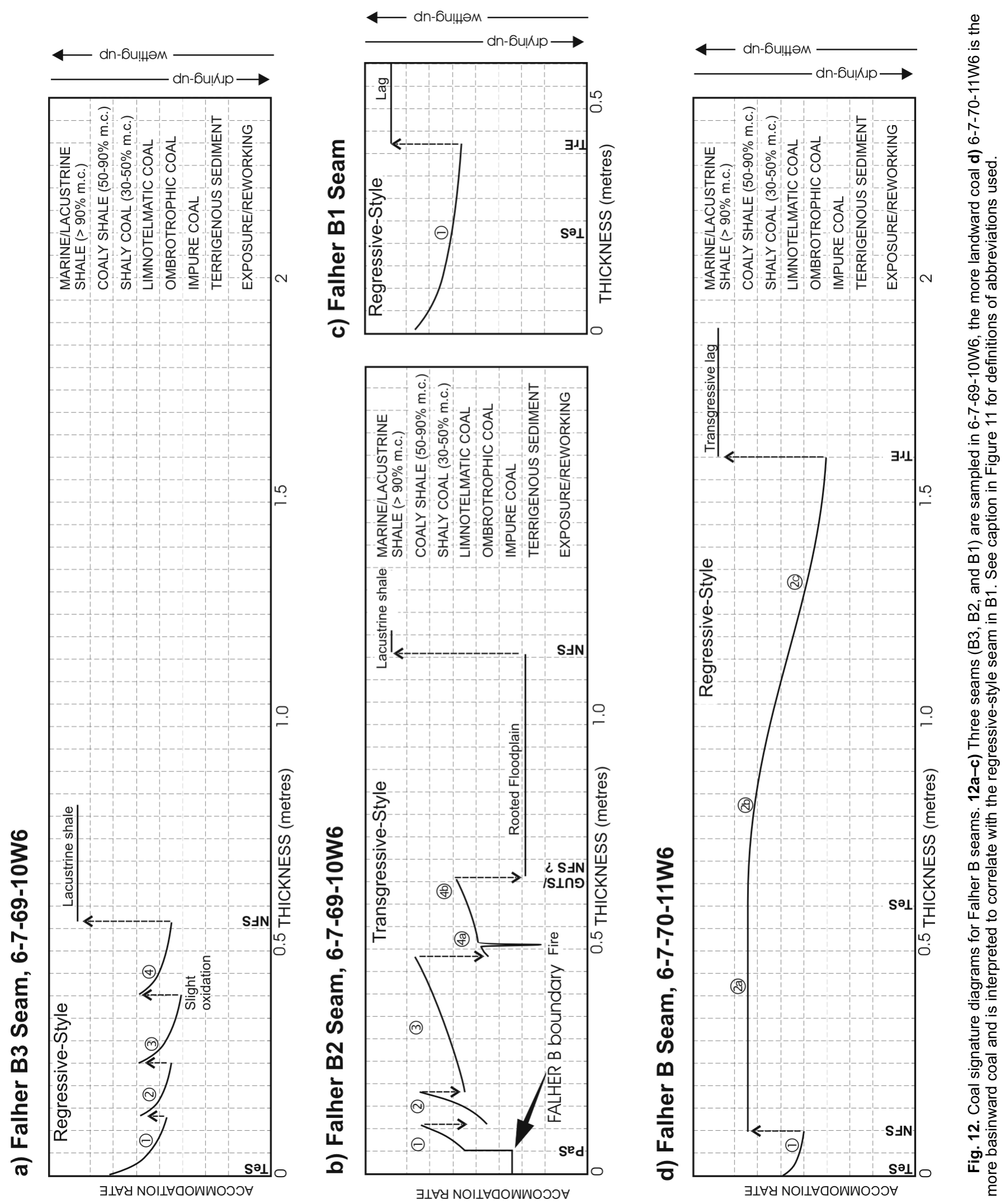

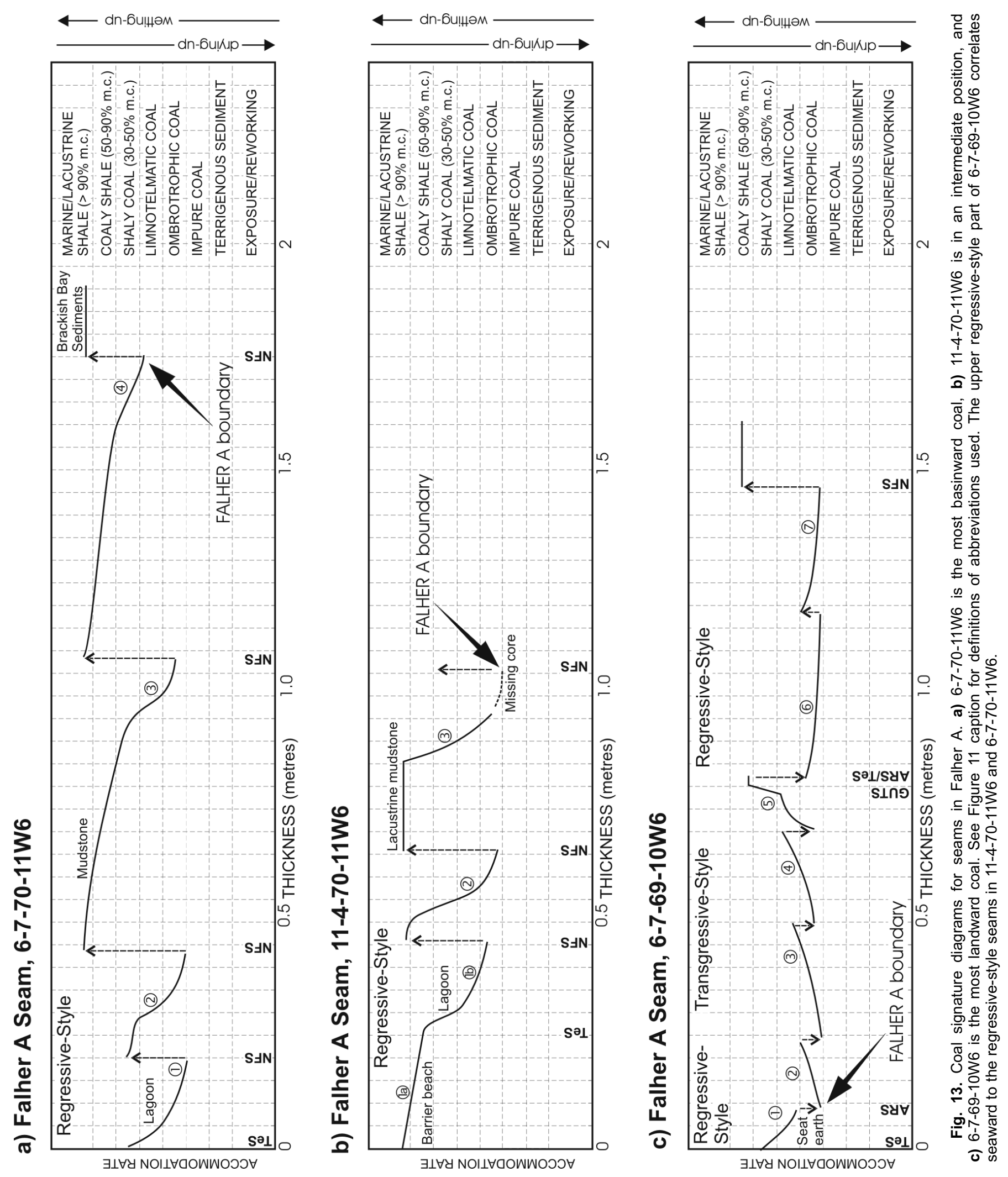
a) Gates A seam

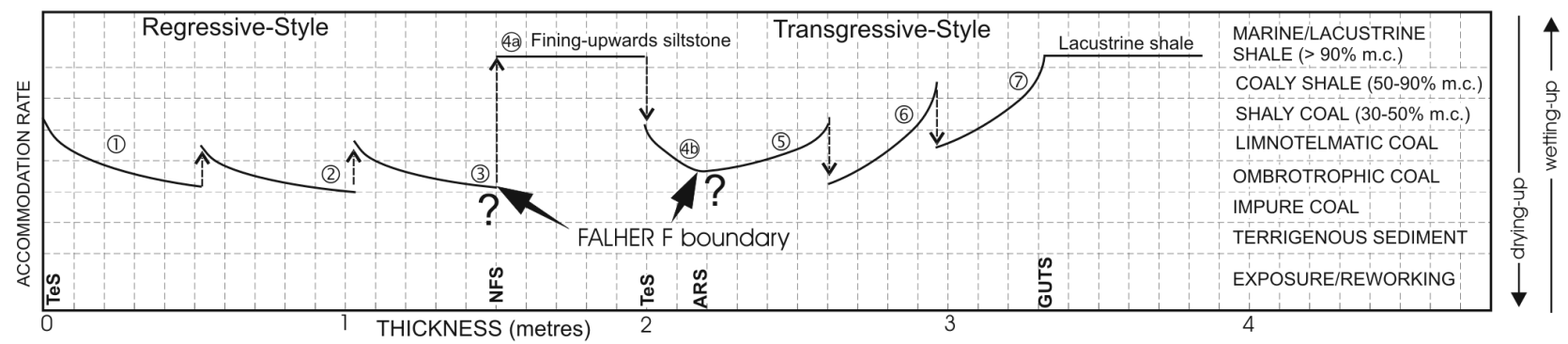

b) Gates B seam

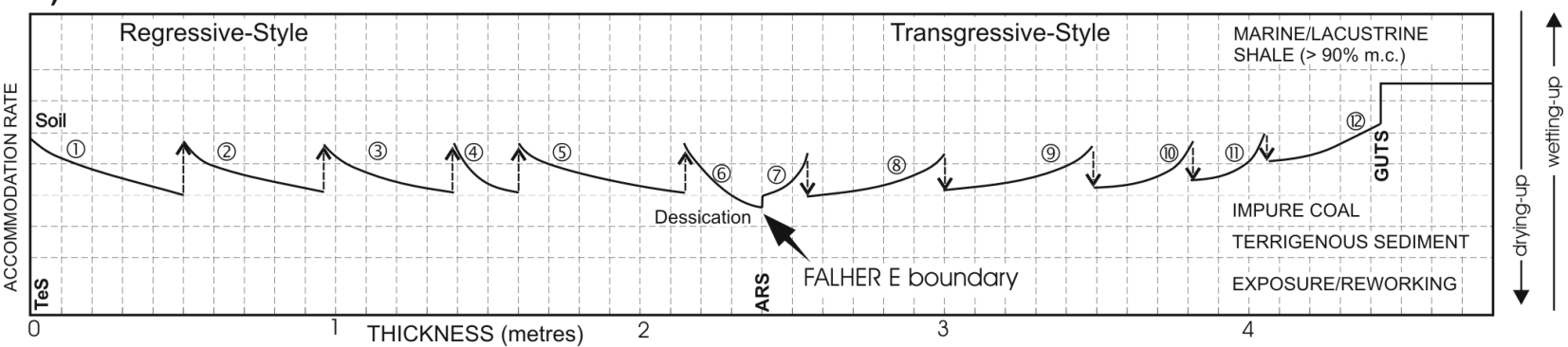

c) Gates C seam

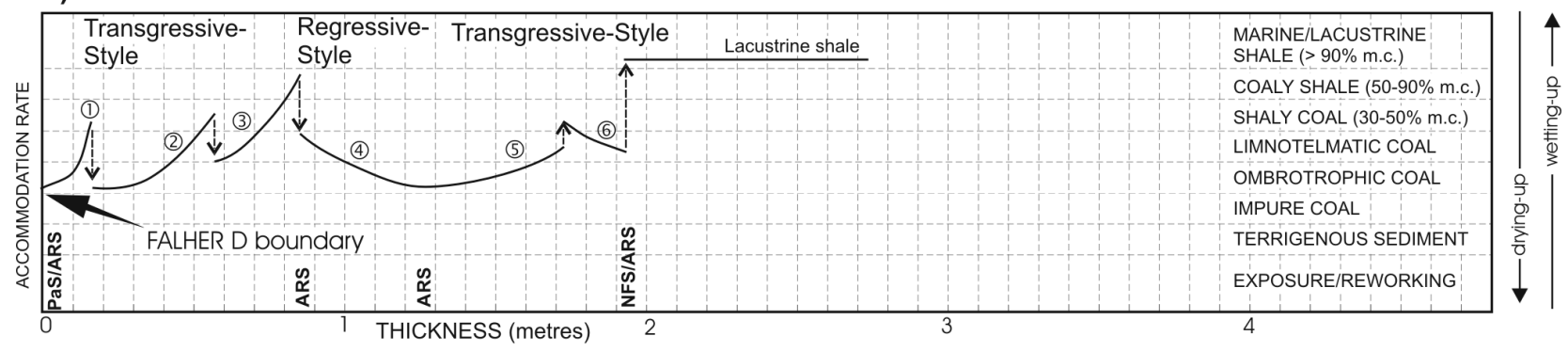

d) Gates D seam

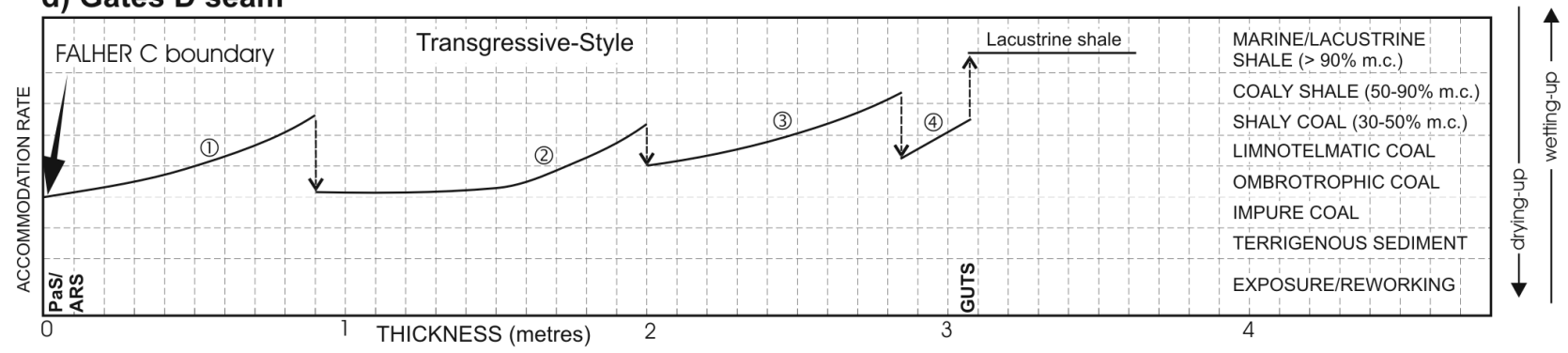

e) Gates E seam

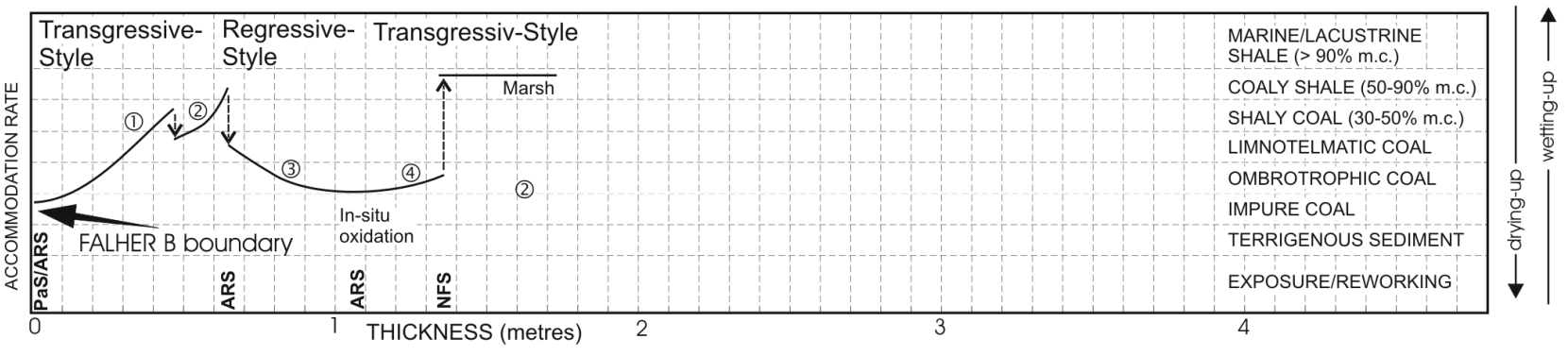

Fig. 14. a-e) Coal signature diagrams for seams $A$ to $E$ (stratigraphically lowest to highest respectively), Gates Formation at Bullmoose Mines. See Figure 11 caption for definitions of abbreviations used. Interpreted correlations to the Falher boundaries (i.e. top of parasequence or parsequence set) are shown for each seam. 


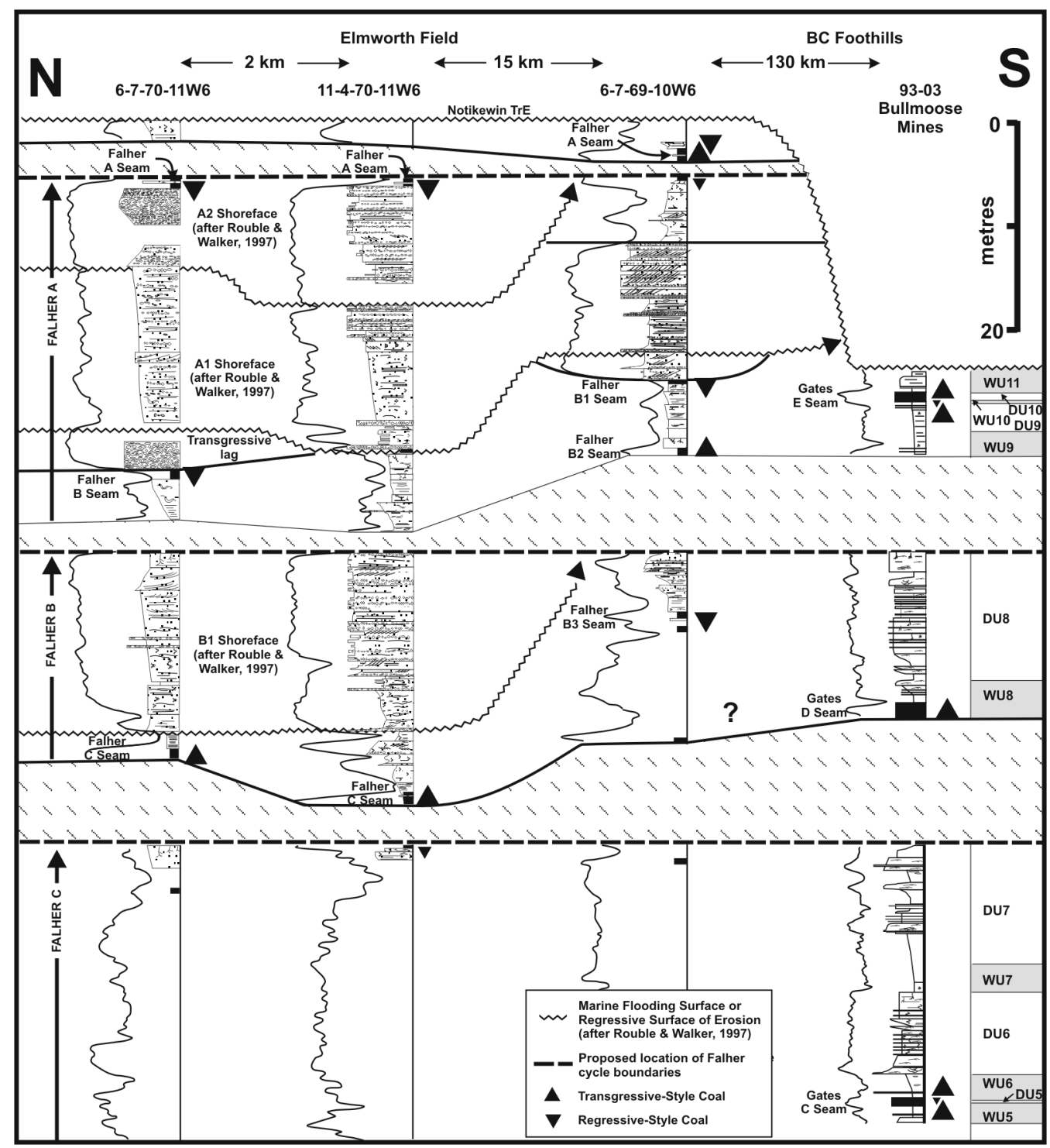

Fig. 15. Summary diagram illustrating the position of sampled coals in relation to Falher Member and Gates Formation stratigraphy. The correlation between BC Foothills and the Elmworth area is speculative, due to lack of available linking data. Interpretion is based on coal analysis data outlined in this study and published outcrop data (Leckie and Walker, 1982). The Gates C Seam shows a mainly transgressive-style, and is interpreted to occur at the base of Falher C. Both transgressive- and regressive-style coals are present. Transgressive-style coals are thought to occur mainly at the base of a Falher cycle as part of the transgressive package (e.g. Falher $\mathrm{C}$ seam). They are often associated with the turn-around point marking the change from decreasing to increasing accommodation conditions. Regressive-style coals occur mainly at the top of a cycle as part of the regressive package (e.g. Falher A, B3 seams), and are similarly associated with the accommodation reversal surface marking a change from increasing to decreasing accommodation.

of $650 \mathrm{~nm}$ after excitation at $436 \pm 8 \mathrm{~nm}$. Maceral and maceral group analyses were carried out in accordance with Australian Standard 2856-1986.

\section{Falher Member CoAls}

Detailed photometric and maceral analyses were undertaken on three seams from different locations (Fig. 8): the Falher A coal (from 6-7-70-11W6, 11-4-70-11W6, and 6-7-69-10W6); the Falher B coal (from 6-7-70-11W6 and 6-7-69-10W6); and the Falher $C$ coal (from 6-7-70-11W6 and 11-4-70-11W6). The analytical results have been used to divide the coal seams into units that show either wetting-upwards or drying-upwards characteristics. The thickness of each coal unit is plotted against the interpreted coal facies change to provide coal signature diagrams (Figs. 11-13). Regressive-style, drying-upwards units typically grade from coaly shale or shaly coal, to a clean coal with high telovitrinite content when peat accumulation and accommodation rates are balanced (i.e. limnotelmatic or ombrotrophic coal). Transgressive-style, wetting-upwards units tend to be initiated by clean, ombrotrophic coal, which grades into shaly coal, or even coaly shale and pure shale. These coal signature diagrams have some similarity with the 
Flözbildungsdiagramme (seam formation diagrams) of Tasch (1960), although the analytical basis is very different.

\section{FalHer C SEAM}

This seam has been analyzed from two samples located approximately $2 \mathrm{~km}$ apart (Fig. 6). It is not clear from correlations alone whether they are two completely separate coals, or whether the 6-7-70-11W6 seam represents an upper split from the 11-4-70-11W6 seam (Fig. 8). The coal signature diagram for the Falher $\mathrm{C}$ seam from 6-7-70-11W6 (Fig. 11a) indicates that the seam was initiated by a PaS which caps a rooted bay fill deposit (Fig. 8). The seam here consists of three wettingupwards units, and is terminated by a GUTS leading into the overlying lacustrine shale, containing some pyrite, lamellibranches, and dispersed vegetation. This pattern is indicative of a transgressive style coal (Fig. 2). In contrast, the Falher C seam from 11-4-70-11W6 (Fig. 11b) begins with a dryingupwards unit overlying a TeS, similar to a regressive-style coal (Fig. 2). Next, an ARS signals a change to transgressive-style coal, followed by wetting-upwards units. Each successive unit encompasses a larger portion of the seam section and terminates with a higher proportion of minerals than the preceding one, which is consistent with a pattern of back-stepping. Two give-up transgressive surfaces are identified, with the uppermost one (GUTS2) forming the upper boundary of the seam (Fig.11b).

Comparison of these Falher $\mathrm{C}$ coal signature diagrams suggests that the upper, transgressive-style part of the Falher $\mathrm{C}$ seam in 11-4-70-11W6 (Units 2-5, Fig. 11b) above the ARS is the landward continuation of the transgressive-style coal in 6-7-70-11W6 (Units 1-3, Fig. 11a). The lower, regressive-style part of the seam in 11-4-70-11W6 below the ARS is probably equivalent to an underlying (unsampled) seam in 6-7-70-11W6 (Fig. 8). The accommodation reversal surface would therefore be equivalent to the interseam bay fill deposits seen in 6-7-70-11W6 and 10-11-71-11W6.

\section{Falher B Seam}

A single seam from the Falher B cycle has been analyzed from 6-7-70-11W6, whereas three separate seams, informally termed B1, B2 and B3 from top to base, have been analyzed from 6-7-69-10W6 (Fig. 8). The B3 seam (Fig. 12a) was initiated by terrestrialization (TeS), and terminated by non-marine flooding (NFS) beneath several metres of carbonaceous shale of lacustrine origin (Fig. 8). Apart from the lowermost, limnotelmatic portion, the coal is very clean, and is probably the product of ombrotrophic, raised-mire conditions. Four dryingupwards units have been distinguished which show evidence of an overall upward decrease in accommodation. It appears to be a regressive-style coal. In contrast, the Falher B2 seam (Fig. 12b) begins with a PaS overlying a thin unit of emergent crevasse splay deposits (Fig. 8). The coal seam consists of four units which are characterized by a signature of repeated upward-wetting, signifying an upward increase in accommodation characteristic of a transgressive-style coal. The top of the coal is capped by either a GUTS or an NFS, depending on the interpretation given to the uppermost coal unit. The Falher B1 seam (Fig. 12c) is of fairly poor quality. The basal portion, immediately overlying floodplain deposits, formed under relatively high accommodation conditions. A TeS marks the initiation of true peat development. The upper part of this regressive-style coal seam has probably been removed by the sharp erosional contact of the overlying tidal delta unit.

The Falher B seam from 6-7-70-11W6 (Fig. 12d) begins with a TeS above brackish bay fill deposits (Fig. 8), and consists of two units characterized by an upward decrease in accommodation. These units are interpreted to represent upward-drying in a regressive-style coal. The lowermost unit is terminated by an NFS. The top of the upper unit has probably been eroded by the overlying transgressive bounding discontinuity; therefore, it is unclear how it was terminated. However, the implication is that the missing, eroded section of coal probably contained an ARS, formed at the turn-around point when peat-forming conditions became wetter prior to development of the transgressive surface.

The cross-sections (Figs. 8, 9) suggest that the Falher B3 seam from 6-7-69-10W6 is a regressive-style coal deposited in a coastal plain setting, with the shoreline being located between the B3 seam in 6-7-69-10W6 and the upper shoreface unit in 7-30-69-11W6 (Fig. 8). The B2 seam is a transgressive-style coal that may correlate to lacustrine strata in $11-4-70-11$ W6 (Fig. 8). The regressive-style B1 seam from 6-7-69-10W6 appears to be the landward equivalent of the regressive-style B seam from 6-7-70-11W6, which may correlate to one of the shingled shoreface units to the north. The more distal seam (6-7-70-11W6) is thicker and contains an extra unit compared to 6-7-69-10W6. This difference may be due to the fact that the former experienced greater subsidence and therefore was thicker and slightly more sensitive to cyclic variations in accommodation. Alternatively, the apparent differences in the seams may be due to differential subsidence.

\section{Falher A Seam}

Our correlations suggest that the same Falher A seam has been analyzed in wells 6-7-70-11W6, 11-4-70-11W6, and 6-7-69-10W6 (Figs. 8, 9). This represents an updip distance of approximately $17 \mathrm{~km}$. A coal signature profile diagram provides a summary of the accommodation trends of each of the Falher A seam samples. In 6-7-70-11W6 (Fig. 13a) the seam is $1.75 \mathrm{~m}$ thick and represents the full core. It begins with a TeS above a shallowing-upwards marine succession, and is capped by an NFS, overlain by brackish bay fill deposits. Four dryingupwards intra-seam units have been distinguished on the basis of alternating coal and sediment bands, and they show an overall pattern of upward thickening. Approximately $2 \mathrm{~km}$ landward, the Falher A seam from 11-4-70-11W6 (Fig. 13b) shows a similar signature which begins with a $\mathrm{TeS}$ that caps a shallowing-upwards marine package. Three intra-seam units have been distinguished on the basis of alternating coal and sediment bands, with each unit capped by an NFS. Together they represent a set of upward-drying units. The uppermost $10 \mathrm{~cm}$ of coal appear to be missing from this core. A further $15 \mathrm{~km}$ landward, 
the Falher A seam from 6-7-69-10W6 (Fig. 13c) was initiated by terrestrialization as indicated by a seam floor comprising wet floodplain (or flood basin) deposits. The lower part of the seam comprises five units, each beginning with very low detrital mineral content. This indicates ombrotrophic, raisedmire conditions at the beginning of each unit. An upward increase in accommodation is indicated by increases in the proportion of dispersal indicators for each unit individually and for the lower seam portion as a whole. This pattern culminates in a GUTS at the top of Unit 5, above which a $5 \mathrm{~cm}$ thick carbonaceous shale indicates that peat formation was temporarily replaced by predominantly clastic sedimentation. The upper part of the seam, which occurs above a combined ARS/TeS, consists of very clean coal. It has been divided into two drying-upwards units. The seam is abruptly overlain by a coaly shale (bay fill deposits), the base of which has been interpreted as an NFS.

Comparison of Figures $13 \mathrm{a}$ and $13 \mathrm{~b}$ reveals that the two most seaward samples from Falher A (6-7-70-11W6 and 11-4-70-11W6) are similar in that the first units of both coals are initiated by terrestrialization and are capped by non-marine flooding surfaces. The two samples differ in that the more distal one (6-7-70-11W6) is thicker, and contains an additional unit. However, these differences may partially stem from the fact that the uppermost part of the 11-4-70-11W6 core appears to be missing due to overdrilling. In any case, both samples indicate a regressive-style coal seam (Fig. 2) with a strong signature of terrestrialization. Fifteen kilometres landward, the same Falher A seam (6-7-69-10W6) overlies wet floodplain deposits (Fig. 9). The accommodation trend signature in this sample (Fig. 13c) is significantly different than the previous two, in that it comprises a regressive-style component, a transgressive-style component and another regressive-style component. This suggests that it is actually a compound seam, comprising coals belonging to separate accommodation cycles, separated by accommodation reversal surfaces. The coal splits basinward along the upper ARS/TeS into two seams (see 7-30-69-11W6, Fig. 8) with an intervening unit of bay fill deposits. Only the upper (regressive) part of the Falher A seam in 6-7-69-10W6 correlates with the Falher A seams in 6-7-70-11W6 and 11-4-70-11W6.

The above discussion suggests that the non-marine component of Falher A does not represent the simple culmination of shoreface progradation. Instead, the initial stages of peat formation occurred under conditions of enhanced accommodation, possibly related to transgression in the back-barrier zone. This peat only formed in the most landward of the three samples (i.e. bottom part of seam in 6-7-69-10W6). This initial phase of peat formation was eventually terminated as accommodation outpaced peat accumulation rates, resulting in a GUTS (Fig. 13c) and local deposition of bay fill sediments, such as occurs in the interseam sediments of 7-30-69-11W4 (Fig. 8). Peat accumulation once again resumed when accommodation slowed down, forming a widespread coal sheet that capped the shoreface deposits in 6-7-70-11W6 and 11-4-7011W6. Therefore, the TeS in 6-7-70-11W4 and 11-4-70-11W4 is the distal equivalent of the ARS in 6-7-69-10W4.

\section{Gates Formation CoAls}

Photometric and maceral analyses were undertaken on five seams from the Gates Formation (A to E), sampled at Bullmoose Mine (Fig. 5). Details and interpretations of the analyses are provided in Diessel et al. (2000), and have been used to construct coal signature diagrams (Fig. 14) by the identification of trends in balanced and unbalanced accommodation/peat accumulation ratios.

\section{Gates A SEAM}

The lowermost Gates Formation coal rests above the Torrens Member shoreface (Fig. 9), equivalent to Falher F (Leckie, 1986a). Because of this setting and its composition, seam A has been described as a strandplain coal within a backbarrier environment (Kalkreuth and Leckie, 1989; Kalkreuth et al., 1991). At the sample locality, the seam is split into the A1 seam approximately $150 \mathrm{~cm}$ thick and the A2 seam $123 \mathrm{~cm}$ thick (Fig. 14a). The Gates A1 seam is initiated by a TeS and is characterized by three drying-upwards units deposited in a regime of overall decreasing accommodation. The interseam unit (50-150 cm thick siltstone) was deposited by a flooding event, possibly a crevasse splay, the base of which may represent an NFS. Peat accumulation in the A2 seam is re-established by terrestrialization, followed by a reversal in the accommodation pattern (ARS) in the form of three wettingupwards units. Their transgressive cyclicity corresponds to an overall increasing accommodation rate. Flooding of the mire and deposition of the lacustrine roof sediment occurs above the GUTS when the accommodation rate exceeds the rate of peat accumulation, with no significant hiatal break apparent.

\section{Gates B SEAM}

The B seam overlies a shoaling-upwards non-marine floodplain deposit (Fig. 9), and is initiated by terrestrialization (TeS: Fig. 14b). At $483 \mathrm{~cm}$, it is the thickest coal in the study, and can be correlated southeast for up to $100 \mathrm{~km}$, where it is equivalent to the Fourth coal (Carmicheal, 1983), a term sometimes used by industry. The bottom half of the seam comprises five small-scale drying-upwards units, formed during overall decreasing accommodation. The uppermost unit appears to represent a significant hiatal surface corresponding to an ARS. In contrast, the upper half of the seam is characterized by six small-scale wettingupwards units deposited during overall increasing accommodation. The top of the seam is marked by a GUTS and is overlain by lacustrine sediments, with no significant hiatal break.

\section{Gates C SeaM}

The $193 \mathrm{~cm}$ thick $\mathrm{C}$ seam was subdivided into seven units (Fig. 14c). Like the previous seams, the $\mathrm{C}$ seam overlies a shallowing-upwards non-marine succession (Fig. 9). Petrographic analysis reveals that this pattern of decreasing accommodation is not continued within the lower half of the coal seam. Instead the basal signature is dominated by wetting-upwards units that indicate overall increasing accommodation, culminating in temporary flooding in the middle of the seam. In this case, the 
base of the $\mathrm{C}$ seam is a combined surface of paludification and accommodation reversal (PaS/ARS). Due to its low detrital mineral content, the upper half of the coal is interpreted as deposited mostly under ombrotrophic conditions, although there appears to be a weak reversal in accommodation trends towards drying-upwards conditions. The top of the seam is sharply overlain by an NFS followed by lacustrine sediments, possibly representing a significant hiatal break.

\section{Gates D Seam}

The D seam abruptly overlies a shoaling-upwards nonmarine succession (Fig. 9). The full seam thickness of $305 \mathrm{~cm}$ was divided into four wetting-upwards units, with each successive unit displaying a stronger signal of increasing accommodation (Fig. 14d). Because of the overall change in pattern from decreasing to increasing accommodation conditions above and below the basal coal boundary, the initial paludification surface is also interpreted as an accommodation reversal surface, and probably represents a depositional hiatus. The upper coal bounding surface against the overlying lacustrine sediments is a non-hiatal give-up transgressive surface (GUTS).

\section{Gates E Seam}

At the sampling site, the Gates E seam is $134 \mathrm{~cm}$ thick and is initiated by paludification ( $\mathrm{PaS})$ above a shallowingupwards clastic succession of lacustrine, crevasse splay, and marsh sediments (Fig. 14e). The lower half of the seam is rich in detrital minerals and is subdivided into two wettingupwards units. Because the underlying clastics have a shallowing-upwards signature, the $\mathrm{PaS}$ may also represent an ARS. A $10 \mathrm{~cm}$ thick interseam unit of carbonaceous shale reflects flooding of the mire, and also contains an ARS, as the overlying peat unit reverses previous accommodation trends with a drying-upwards pattern from limnotelmatic to ombrotrophic coal, with some evidence of a very low accommodation/peat ratio where in situ oxidation occurs (Unit 3). Another ARS marks the subtle transition back to wetting-upwards conditions (Unit 4). The upper boundary of the seam is interpreted as an NFS, thought to represent an abrupt rise in accommodation resulting in deposition of shallowwater sediments. Overlying this is the transgressive erosion surface marking the base of the Notikewin Member ( $\operatorname{TrE}$ surface in Fig. 9).

\section{Discussion}

\section{Correlations from Non-Marine to Marine CyCles}

A flooding event, such as a marine transgression, occurs at that point in a depositional cycle where the accommodation created by a combination of tectonic subsidence, eustacy and subsurface compaction exceeds the volume of the accumulating sediments. In marine cycles, this flooding event produces a parasequence boundary, which is "a surface separating younger from older strata across which there is evidence of an abrupt increase in water depth...with a minor hiatus indicated" (van Wagoner et al., 1990, p. 8). A marine parasequence boundary is therefore also an accommodation reversal surface, separating relatively shallow water facies below from relatively deeper water facies above. This marine flooding surface is assumed to have a correlative surface in the coastal plain (van Wagoner et al., 1990). In our model of the peat accommodation/accumulation ratio (Fig. 2) we illustrate how a marine flooding surface may translate landwards into either an NFS, or a non-hiatal GUTS above a coal seam, depending on the decreasing magnitude of base-level rise. These two surfaces may or may not be associated with an accommodation reversal surface, depending on whether sediments are deposited and/or preserved during the ensuing accommodation rise. This model therefore suggests that a parasequence boundary will change laterally from an abrupt, hiatal surface in the marine realm, to a gradational, non-hiatal surface or interval in the non-marine realm. In this section we explore this idea further by attempting to identify parasequence boundaries in the analyzed coal samples, and by attempting to correlate and compare coal seams from the Falher Member and Gates Formation.

The Falher cycles comprise marine to non-marine stratal packages, formed by accommodation cycles that produced transgressive-regressive shoreline cyclicity. In this fashion they resemble parasequences and parasequence sets. However, as summarized earlier, the upper bounding surfaces of individual cycles have never been clearly defined, with different authors placing the bounding surfaces at the base, at the top, or somewhere within the non-marine component of each cycle. The clastic wetting- and drying-upwards successions in the non-marine Gates Formation also show strong evidence of accommodation cyclicity, although the precise location of bounding surfaces is again not clearly defined. Combining our coal analysis with existing stratigraphic correlations, we have identified key accommodation reversal surfaces which can be used to subdivide the accommodation cycles, and use these to link the accommodation cycles of the Falher Member in Figure 7 to the Gates Formation wetting- and drying-upwards successions illustrated in Figure 9.

Precise correlations between the Falher marine cycles and the Gates non-marine cycles at Bullmoose Mine $(150 \mathrm{~km}$ to the west) are difficult to construct because of the limited data sets (subsurface wireline logs and core versus outcrop data) and the lack of unique stratigraphic markers to link the marine and nonmarine deposits. However, outcrop-based correlation between Mt. Spieker (Leckie and Walker, 1982) and Bullmoose Mine ( $5 \mathrm{~km}$ to the southwest) can be used to make some inferences on regional stratigraphy.

The upper part of the Mt. Spieker outcrop illustrated in Figure 10 is composed of a coarsening- and shoaling-upwards, wave-dominated shoreface, incised by a conglomeratic fluvial channel. It is interpreted to be equivalent to Falher F and is overlain by the Gates A seam (Leckie, 1986a). Based on its position, and the occurrence of a basal TeS, the lower half of this seam, with its drying-upwards signature (Fig. 14a), is clearly part of the same shoaling-upwards succession as the underlying shoreface (DU1; Fig. 9). The top part of the seam shows a wetting-upwards 
signal (Units 5-7; Fig. 14a) and is therefore part of the WU2 succession, which we suggest is the equivalent to the transgressive component of Falher E (Fig. 9). The Falher F parasequence boundary corresponds either to the NFS at the base of the interseam strata (Unit 4a), or to the ARS above. In either case, the parasequence boundary falls in the middle of the Gates A seam, and marks the overall change from regressive to transgressive conditions.

The Gates A seam at Bullmoose Mine is capped by floodplain or lacustrine carbonaceous shale (Fig. 10), probably equivalent to Falher E. The Gates B seam sits above this, and is present in both locations. Similar to the Gates A seam, this coal is subdivided into a lower drying-upwards succession (Units 1-6) associated with the underlying DU2, and an overlying wetting-upwards component (Units 7-12) associated with WU3 (Fig. 14b). The Falher E parasequence upper boundary lies in the middle of this coal seam, corresponding to an accommodation reversal surface.

Falher D commences with the upper half of the Gates B seam (WU3). At Mt. Spieker, this is followed by a complex unit of sandstone and conglomerate, overlain by $10-15 \mathrm{~m}$ of carbonaceous shale and siltstone, and a thin coal, interpreted as the Gates $\mathrm{C}$ seam. This package is interpreted as fluvial, estuarine, and floodplain deposits, grading into beach and marine deposits (i.e. Falher D) to the north. At Bullmoose Mine the Falher D cycle consists of lacustrine, floodplain, marsh, and fluvial sediments (Fig. 9). On Mt. Spieker, Falher D is capped by an unnamed coal seam, which is in turn overlain by carbonaceous shale and siltstone (Leckie and Walker, 1982) and another coal seam. The lower, unnamed coal seam in Figure 10 probably corresponds to the marsh sediments in WU4 (Fig. 9). The overlying coal is the Gates C seam. Analysis of this coal from the Bullmoose Mine site shows that it contains four accommodation reversal surfaces; a basal PaS/ARS, two middle ARS, and an upper NFS/ARS (Fig. 14c), indicating an overall change in coal style from transgressive to regressive and back to transgressive. This pattern is completely opposite to that of the A and B seams, and is more difficult to interpret. The basal and upper accommodation reversal surfaces are both possible Falher D parasequence boundaries because they are both associated with an abrupt increase in accommodation. However, the lower $\mathrm{PaS} / \mathrm{ARS}$ marks the initial turn-around in accommodation and beginning of non-marine flooding, and is therefore the best candidate. This suggests that in Figure 9 Falher D comprises two wetting- to drying-upwards successions; WU3 to DU3 and WU4 to DU4, which both represent non-marine clastic accommodation cycles that may correlate to one or more of the Falher D transgressive-regressive shoreface cycles documented by Casas and Walker (1997).

At the top of Mt. Spieker is another unit of marine sandstone and conglomerates, equivalent to Falher C (Fig. 10). Caddell (2000) suggests that this succession can be further subdivided into two parasequences in outcrop. There is no capping coal preserved in this outcrop. At Bullmoose Mines (Fig. 9), Falher $\mathrm{C}$ is inferred to comprise three non-marine wetting- to drying-upwards successions; WU5 to WU6 (i.e. the Gates C seam), WU6 to DU6 (lacustrine to floodplain facies) and WU7 to DU7 (lacustrine to floodplain facies). Above this occurs the Gates D seam, which comprises four wetting-upwards units indicating a step-wise increase in accommodation, culminating in a GUTS (Fig. 14d). This signature clearly places it within a wetting-upwards succession. The most likely candidate for the Falher C parasequence boundary is the PaS/ARS (Fig. 14d) at the base of the Gates D seam, which marks the change from drying-upwards conditions (lacustrine to floodplain facies in DU7) to wetting-upwards conditions (transgressive coal in WU8). This suggests that the Gates D seam actually sits in the basal part of Falher B (Figs. 9 and 15).

Comparison of the Gates D seam (Fig. 14d) with the Falher C seams (Fig. 11) shows that the seam at 6-7-70-11W6 (Fig. 11a) and equivalent part of the seam at 11-4-70-11W6 (Units 2-5) have a similar wetting-upwards style, also placing them at the base of the Falher B parasequence (or parasequence set). The single unit of drying-upwards coal in 11-4-70-11W6 (Unit 1 in Fig. 11b) is therefore interpreted to represent the uppermost portion of Falher $\mathrm{C}$, and is equivalent to the crevasse splay, marsh and floodplain strata of DU7 (Fig. 9). The parasequence boundary therefore lies below the coal in some places, and within it in other places.

The Gates E seam (Fig. 14e) is very similar to the Gates C seam, with a basal PaS/ARS surface indicating an initial rise in accommodation, followed by a transgressive-style coal. An accommodation reversal surface marks a change into a regressive-style coal formed under ombrotrophic conditions, followed by a subtle turn-around back into a transgressive-style coal. The upper NFS abruptly terminates the coal. We interpret this pattern as an indication of coal seam amalgamation, with the basal surface of the seam being the most likely position for a parasequence boundary. Above this is a widespread marsh deposit, which may indicate the beginning of another accommodation cycle (WU11) that preceded the Notikewin shoreface (Fig. 9).

The Gates D seam has been interpreted to sit in the transgressive basal portion of Falher B, and the Gates E seam is the only other coal between the Gates D seam and the Notikewin Member in the Bullmoose Mine area (Fig. 9). The relationship between this coal and the Falher A and B cycles is not entirely clear, because there are no equivalent exposures at Mt. Spieker to provide outcrop to subsurface correlations. Possible interpretations are that the Gates E seam belongs to 1) the top of Falher B, or 2) the top or base of Falher A . Because the petrographic analysis signature (Fig. 14e) suggests that this coal sits at the base of a parasequence, we suggest that the most likely position for the Gates E seam is at the base of Falher A, marking the initial transgression indicated in Figure 15. This would make it laterally equivalent to the Falher B coals. The coal signature in Figure 12a indicates that the Falher B3 seam at 6-769-10W6 is a regressive-style coal, and is probably formed in a coastal plain environment at the same time as the Falher shoreface. It therefore belongs at the top of the Falher B parasequence. In contrast, the Falher B2 seam at 6-7-69-10W6 has a 
transgressive-style signature (Fig. 12b), similar to the bottom half of the Gates E seam (Units 1 and 2 in Fig. 14e) and thus belongs to the Falher A parasequence. We suggest that the Falher B parasequence boundary lies at the base of these two coal seams (Fig. 15). The Falher B1 seam (6-7-69-10W6) and Falher B seam (6-7-70-11W6) share a similar regressive-style coal signature (Figs. 13d, e), which may be equivalent to Unit 3 in Gates seam E (Fig. 14e). This indicates a temporary pause in overall transgression at the beginning of the Falher A parasequence, until non-marine wetting-upwards conditions were re-established (Unit 4 in Fig. 14e).

This interpretation suggests that none of the Gates Formation coals in Figure 9 are equivalent to the subsurface Falher A coals shown in Figure 12, and that most of the Falher A parasequence at Bullmoose Mine has been removed by the transgressive erosion surface ( $\mathrm{TrE}$ ) at the base of the Notikewin shoreface (Fig. 15). However, the Falher A parasequence appears to be fully developed in the Deep Basin subsurface (Fig. 7). The most landward Falher A coal sample analyzed (6-7-69-10W6; Fig. 13c) shows a regressive-transgressiveregressive-style pattern similar to the underlying Falher B1, B2 and B3 (Fig.13a-c). We suggest that the non-marine equivalent to the Falher A parasequence boundary sits at the turn-around point between transgressive-style and regressive-style coal (i.e. between units 1 and 2 in 6-7-69-10W6; Fig. 13c). This is equivalent to the top of the regressive-style seams in 6-7-70-11W6 and 11-4-70-11W6 (Fig. 13 a, b). The parasequence boundary therefore lies below the coal in some places, and within it in other places, similar to the Falher C parasequence.

\section{ImPlications for Non-Marine SEquence StratigraPhy}

In sequence stratigraphic terms, one outcome of the Falher Member and Gates Formation stratigraphic analysis is that the identification of flooding surfaces, and therefore parasequence boundaries, is not straightforward in non-marine strata. Most researchers agree that the Falher shorefaces are characterized by a thin transgressive base, overlain by progradational shoreface sands. The surface separating underlying non-marine sediments from overlying marine sediments is a transgressive surface of erosion, sometimes modified by a regressive surface of erosion, if no transgressive deposits are preserved (Rouble and Walker, 1997; Casas and Walker, 1997). The transgressive surface of erosion may be the most easily recognizable surface associated with flooding, but our coal analysis suggests that the turn-around from regressive to transgressive conditions is first evident in the non-marine strata, and is particularly evident in association with the coal as a non-marine accommodation reversal surface. Coals may form above and/or below such a surface, and what appears to be a laterally continuous coal is in fact a compound coal spanning one or more accommodation reversal surfaces.

In the siliciclastic marine realm, a parasequence boundary is typically represented by an abrupt surface with deeper-water facies sitting directly above shallower-water facies, with often little or no evidence of the accommodation turn-around preserved. This occurs because initial transgression forms embayments or estuaries that trap sediment in the lower coastal plain, resulting in a diminished sediment supply rate to the shoreline and shelf. The locus of sedimentation shifts updip and onshore, resulting in landward translation of the shoreline (Bohacs and Suter, 1997). Enhanced trapping of sediment in the non-marine realm means that the turn-around in accommodation will have a more gradational expression. Shifts to onshore sedimentation accumulation during transgression will be accentuated in foreland basin settings where accommodation increases landward.

Coal seams may develop during both increasing and decreasing accommodation conditions, as the groundwater table responds to changing base level conditions. A coal seam dominated by a transgressive-style, upwards-increasing accommodation signature most likely sits within the transgressive part of a larger-scale stratal package. Therefore the initial surface recording an increase in accommodation lies at the base of the coal with the combined ARS/PaS, rather than at the top of the coal with the GUTS, NFS or FS. Transgressive-style coals occur at the bottom of parasequences (e.g. Gates seam D, Falher C seam in 6-7-70-11W6, Falher B2 seam in 6-7-69-10W6).

A coal seam dominated by a regressive-style, upwardsdecreasing accommodation signature most likely sits within the regressive part of a larger-scale stratal package. Therefore the upper bounding surface of the coal (GUTS, NFS or FS) marks the point at which accommodation increases significantly, and is therefore the most likely position for a parasequence boundary (e.g. Falher B3 seam in 6-7-69-10, Falher B seam in 6-7-70-11W6).

A coal seam characterized by both transgressive-style and regressive-style components must span more than one accommodation cycle. If the signature shows a straightforward pattern of regressive-style coal replaced by transgressive-style coal, then the transition surface between these two styles corresponds to an accommodation reversal surface marking the change from drying-upwards to wetting-upwards conditions. Thus the parasequence boundary here lies within the coal seam. Examples of this type of coal are Gates A and B seams, and Falher $C$ seam in 11-4-70-11W6. In contrast, a coal seam with a transgressive- to regressive-style signature has an internal accommodation reversal surface that marks a change from wetting-upwards to drying-upwards conditions. If such a coal sits above a regressive shoreface (e.g. Falher A seam in 11-4-70-11W6) it signifies that the coal cannot be lumped in as part of the overall shallowing-upwards succession, and that it is separated from the apparently conformably underlying deposits by an accommodation reversal surface.

Both transgressive- and regressive-style coal seams are present in the Falher Member and co-eval Gates Formation nonmarine deposits. This indicates that the non-marine components of the Falher cycles did not accumulate over a single transgressive or regressive event, but actually represent a number of accommodation cycles. Coal seams appear to be at least as sensitive as shoreface deposits to changes in relative sea level. 


\section{Conclusions}

1) The Falher-Gates interval of the Western Canadian Foreland Basin preserves a detailed record of transgressive and regressive coastal sedimentation and equivalent downdip marine and updip terrestrial strata, including numerous thick coal seams. The range of high quality data available from core, wireline $\log$, and outcrop provides valuable insight on how to interpret and correlate non-marine to marginal marine strata.

2) Concepts regarding the expression of parasequences and their flooding surface boundaries in marine rocks need to be significantly modified in the terrestrial realm.

3) Sharp hiatal parasequence boundaries in the marine realm such as flooding surfaces and wave/tidal ravinement surfaces may correlate updip to packages of rocks that pass gradationally from transgressive to regressive units and preserve the transitions between the two. Non-marine sediments may accumulate during and following shoreline regression, and prior to and during shoreline transgression. The exact style and preservation of the non-marine stratigraphic package depends on the balance between accommodation rate and sediment flux at the time of deposition.

4) Coaly rocks are an effective tool for sequence stratigraphic interpretation and correlation of non-marine to marginal marine sediments. In many cases they provide the best and perhaps only method of high resolution correlation.

5) Coals may occur in both regressive and transgressive styles, and may initiate or terminate parasequences. Coals may also occur as compound coals that span more than one parasequence and contain internal discontinuity surfaces. Coal compositional characteristics provide key information in determining their stratigraphic position and the stratigraphic behaviour of surrounding strata.

\section{ACKNOWLEDGMENTS}

This paper is part of a larger ongoing research project into the sequence stratigraphy of non-marine to marginal marine strata formed under varying accommodation settings. We wish to thank our collaborative partners who have provided financial or technical support: Pan Canadian Energy Corporation (now EnCana Corporation), who also kindly gave us permission to use and publish their data, Bullmoose Mine, the Australian Research Council, and the NSW (Australia) Department of Mineral Resources. We would like to thank Gareth Chalmers for his analytical work, Richard Rouble for fruitful discussions and access to his original sections, Bruce Misanchuk for helping to initiate the project and providing much early data, Lorne Rosenthal for providing critical analysis and feedback, and Brian Zaitlin for providing crosssections and well correlations. Finally, we appreciate the thoughtful formal reviews provided by Howard Feldman and Kevin Bohacs.

\section{REFERENCES}

Aitken, J.F. and Flint, S.S. 1995. The application of high resolution sequence stratigraphy to fluvial systems: a case study from the Upper Carboniferous Breathitt Group, eastern Kentucky, USA. Sedimentology, v. 42 , p. $3-30$.

Arnott, R.W.C. 1993. Sedimentological and sequence stratigraphic model of the Falher 'D' pool, Lower Cretaceous, northwestern Alberta. Bulletin of Canadian Petroleum Geology, v. 41, p. 453-463.

Barclay, J.E., Krause, F.F., Campbell, R.I. and Utting, J. 1990. Dynamic casting and growth faulting: Dawson Creek graben complex, Carboniferous-Permian Peace River Embayment, western Canada. Bulletin of Canadian Petroleum Geologists, v. 38a, p.115-144.

Bohacs, K.M. and Suter, J. 1997. Sequence stratigraphic distribution of coaly rocks: Fundamental controls and examples. The American Association of Petroleum Geologists Bulletin, v. 81, p. 1612 - 1639.

Boron, D.J., Evans, E.W. and Petersen, J.M. 1987. An overview of peat research, utilization, and environmental considerations. International Journal of Coal Geology, v. 8, p.1-31.

Boyd, R. and Diessel, C.F.K. 1994. The application of sequence stratigraphy to non-marine clastics and coal. In: Second High-Resolution Sequence Stratigraphy Conference, Tremp, Spain. H.W. Posamentier and E. Mutti (Convs.), p. 13-20.

and 1995. The effects of accommodation, base level and rates of peat accumulation on coal measure architecture and composition. American Association of Petroleum Geologists 1995 Annual Convention, Abstracts and Programs, p 12a.

Caddell, E. M. 2000. Sedimentology and Stratigraphy of the Falher C Member, Spirit River Formation, Northeastern British Columbia. MSc. thesis, University of Calgary, Calgary, Alberta, 242p.

Cant, D.J. 1983. Spirit River Formation - a stratigraphic-diagenetic gas trap in the deep basin of Alberta. American Association of Petroleum Geologists Bulletin, v. 67, p. 577-587.

1984. Development of shoreline-shelf sand bodies in a Cretaceous epeiric sea deposit. Journal of Sedimentary Petrology, v. 54, p. 541-556.

1988. Regional structure and development of the Peace River Arch, Alberta: a Palaeozoic failed-rift system. Bulletin of Canadian Petroleum Geology, v. 36, p. 284-295.

1995. Sequence stratigraphic analysis of individual depositional successions: effects of marine/non-marine sediment partitioning and longitudinal sediment transport, Mannville Group, Alberta foreland basin, Canada. The American Association of Petroleum Geologists Bulletin, v. 79 , p. $749-762$.

and Stockmal, G.S.1993. Some controls on sedimentary sequences in foreland basins: examples from the Alberta Basin. In: L.E Frostick and R.J. Steel (eds.). Tectonic Controls and Signatures in Sedimentary Successions. International Association of Sedimentologists Special Publication 20, p. 49-66.

and Abrahamson, B. 1994. Isopach of transgressive system Mannville Group. Map 1:2,000,000. Geological Survey of Canada, Open File 3090. and 1996. Regional distribution and internal stratigraphy of the Lower Mannville. Bulletin of Canadian Petroleum Geology, v. 44, p. $508-529$.

Carmichael, S.M.M. 1983. Sedimentology of the Lower Cretaceous Gates and Moosebar Formations, Northeast Coalfields, British Columbia. PhD thesis, University of British Columbia,Vncouver, B.C. 285p.

1988. Linear estuarine conglomerate bodies formed during a mid-Albian marine transgression; 'Upper Gates' Formation, Rocky Mountain Foothills of North-eastern British Columbia. In: Sequences, Stratigraphy, Sedimentology: Surface and Subsurface. D.P. James and D.A. Leckie (eds.) Canadian Society of Petroleum Geologists, Memoir 15, p. 49-62.

Casas, J.E. and Walker, R.G. 1997. Sedimentology and depositional history of Units C and D of the Falher Member, Spirit River Formation, west-central Alberta. Bulletin of Canadian Petroleum Geology, v. 45, p. 218-238.

Cecil, C.B., Stanton, R.W., Dulong, F.T. and Renton, J.J. 1979. Some geologic factors that control mineral matter in coal. West Virginia Geological And Economic Survey Bulletin B 37/1. p. 43-56. 
Chalmers, G.R.L. 2002. Characteristics of Low Accommodation Coal Seams, Lloydminster Area, Western Canadian Sedimentary Basin. MSc thesis, University of Newcastle, Newcastle, N.S.W., Australia, 212p.

Demarest, J.M. and Kraft, J.C. 1987. Stratigraphic record of Quaternary sea levels: implications for more ancient strata. In: Sea Level Fluctuations and Coastal Evolution. D. Nummudal, O.H. Pilkey and J.D. Howard. (eds.), Society of Economic Paleontologists and Mineralogists Special Publication 41, p. 223-240.

Diessel, C.F.K. 1992. Coal-bearing Depositional Systems. Springer-Verlag, Berlin, 721p.

1998. Sequence stratigraphy applied to coal seams: two case histories. In: Shanley, K.W. and McCabe, P.J. (eds.). Relative Role of Eustacy, Climate and Teconism in Continental Rocks. SEPM Special Publication 59, p. 151-173.

and Boyd, R. 1994. Sequence stratigraphy and its application to coal geology. Short Course Notes, $28^{\text {th }}$ Newcastle Symposium, Newcastle, N.S.W., Australia, 54p.

and Gammidge, L.C. 1998. Isometamorphic variations in the reflectance and fluorescence of vitrinite - a key to the depositional environment. International Journal of Coal Geology, v. 36, p. 167 - 222.

Boyd, R., Wadsworth, J., Leckie, D., and Chalmers, G. 2000. On balanced and unbalanced accommodation/peat accumulation ratios in the Cretaceous coals from Gates Formation, Western Canada, and their sequence-stratigraphic significance. International Journal of Coal Geology, v. 43 , p. $143-186$.

Douglas, R.J.W. 1970. Carboniferous and Permian. In: Geology and Economic Minerals of Canada. R.J.W. Douglas (ed.). Geological Survey of Canada, Economic Geology Report no. 1, p. 411-421.

Frenzel, B. 1983. Mires - repositories of climatic information or self-perpetuating ecosystems. In: Mires: Swamp, Bog, Fen and Moor. General Studies. A.J.P. Gore (ed.). Elsevier, Amsterdam, p. 35-65.

Hampson, G.J., Stollhofen, H. and Flint, S.S. 1999. A sequence stratigraphic model for the Lower Coal Measures, (Upper Carboniferous), of the Ruhr district, north west Germany. Sedimentology, v. 6, p. 1199-1231.

and 2001. Reply to Discussion: A sequence stratigraphic model for the Lower Coal Measures, (Upper Carboniferous), of the Ruhr district, north west Germany. Sedimentology, v. 48, p. 1179-1186.

Heckel, P.H. 1986. Sea-level curve for Pennsylvanian eustatic marine transgressive-regressive depositional cycles along midcontinent outcrop belt, North America. Geology, v. 14, p. 33-334.

Jackson, P.C. 1984. Paleogeography of the Lower Cretaceous Mannville Group of western Canada. In: Elmworth - Case Study of a Deep Basin Gas Field. Masters. J.A. (ed.). American Association of Petroleum Geologists, Memoir 38, p. 49-78.

Jervey, M.T. 1988. Quantitative geological modeling of siliciclastic rock sequences and their seismic expression. In: Sea Level Changes: An Integrated Approach. C.K Wilgus, B.S. Hastings, C.A Ross, H.W. Posamentier, J. van Wagoner and C.G.St.C. Kendall (eds.). Society of Economic Paleontologists and Mineralogists Special Publication 42, p. 47-70.

Kalkreuth, W. and Leckie, D.A. 1989. Sedimentological and petrographical characteristics of Cretaceous strandplain coals: a model for coal accumulation from the North American Western Interior Seaway. In: Peat and Coal: Origin, Facies, and Depositional Models. P.C. Lyons and B. Alpern, (eds.). International Journal of Coal Geology, v. 12, p. 381-424.

Leckie, D.A. and Labonté, M. 1991. Gates Formation (Lower Cretaceous) coals in Western Canada: a sedimentological and petrographical study. In: Contributions to Canadian Coal Geoscience, Geological Survey of Canada, Paper 89-9, p. 14-25.

Kauffman, E.G. 1977. Geological and biological overview: Western Interior Cretaceous Basin. Mountain Geologist v. 14, p. 79 - 99.

Leckie, D.A. 1983. Sedimentology of the Moosebar and Gates Formations (Lower Cretaceous). PhD thesis, McMaster University, Hamilton, Ontario, $515 \mathrm{p}$.

1986a. Rates of controls and sand-body geometrics of transgressiveregressive cycles: Cretaceous Moosebar and Gates Formations, British Columbia. American Association of Petroleum Geologists Bulletin, v. 70, p. $516-535$. 1986b. Petrology and tectonic significance of Gates Formation (early Cretaceous) sediments in northeastern British Columbia. Canadian Journal of Earth Sciences, v. 23, p. 129-141.

and Smith, D.G. 1992. Regional setting, evolution, and depositional cycles of the Western Canada Foreland Basin. In: Foreland Basins and Fold Belts. R.W. Macqueen and D.A. Leckie (eds.). American Association of Petroleum Geologists Memoir 55, p. 9-46.

and Walker, R. G. 1982. Storm- and tide-dominated shorelines in the Cretaceous Moosebar-Lower Gates interval: outcrop equivalents of the Deep Basin gas trap in Western Canada. American Association of Petroleum Geologists Bulletin, v. 66, p. 138-157.

, Vanbeselaere, N.A. and James, D.P. 1997. Regional sedimentology, sequence stratigraphy and petroleum geology of the Mannville Group, southern Saskatchewan. In: Petroleum Geology of the Cretaceous Mannville Group Western Canada. S.G. Pemberton and D.P. James (eds.). Canadian Society of Petroleum Geologists Memoir 18, p. 211-262.

Masters, J.A. 1979. Deep basin gas trap, western Canada. The American Association of Petroleum Geologists Bulletin, v. 63, p. 152-181.

1984. Lower Cretaceous oil and gas in western Canada. In: Elmworth Case Study of a Deep Basin Gas Field. J.A. Masters (ed.). American Association of Petroleum Geologists Memoir 38, p. 1-33.

McCabe, P.J. 1993. Sequence stratigraphy of coal-bearing strata. In: Sequence Stratigraphy of Coal-Bearing Strata: Field Trip Guidebook and Short Course Supplement, J.A. Breyer, A.W. Archer and P.J. McCabe (eds.). American Association of Petroleum Geologists Short Course, New Orleans, p. 81.

McCarthy, P.J. and Plint, A.G. 2001. Recognition of interfluve sequence boundaries: Integrating paleopedology and sequence stratigraphy. Geology, v. 26 , p. $387-390$.

McLearn, F. H. 1923. Peace River Canyon coal area, British Columbia: Geological Survey of Canada, Summary Report 1922, part B, p. 1-46.

McLean, J.R. 1977. The Cadomin Formation, stratigraphy, sedimentology and tectonic implications. Bulletin of Canadian Petroleum Geology, v. 25, p. $792-827$.

1982. Lithostratigraphy of the Lower Cretaceous coal-bearing sequence, Foothills of Alberta. Geological Survey of Canada, Paper 80-29, 46p.

Montgomery, S.1., Tabet, D.E. and Barker, C.E. 2001. Upper Cretaceous Ferron Sandstone: Major coalbed methane play in central Utah. Bulletin of American Association of Petroleum Geologists, v. 85, p. 199-219.

O'Connell, S.C., Dix, G.R. and Barcley, J.E. 1990. The origin, history and regional structural development of the Peace River Arch, Western Canada. Bulletin of Canadian Petroleum Geology, v. 38a, p. 4-24.

Pate, C. 1988. A comparison of isopach maps and total subsidence maps: implications for basin development and sandstone distribution during the lower Cretaceous in the deep basin area of Alberta and British Columbia. In: Sequences, Stratigraphy, Sedimentology: Surface and Subsurface, D.P. James and D.A. Leckie (eds.). Canadian Society of Petroleum Geologists, Memoir 15, p. 553-562.

Plint, A.G., McCarthy, P.J. and Faccini, U.F. 2001. Non-marine sequence stratigraphy: updip expression of sequence boundaries and systems tracts in a high resolution framework, Cenomanian Dunvegan Formation, Alberta foreland basin, Canada. American Association of Petroleum Geologists Bulletin, v. 85, p. 1967-2001.

Posamentier, H.W. and Vail, P.R. 1988. Eustatic control on clastic sedimentation II - sequence and systems tract models. In: Sea Level Changes: An Integrated Approach. C.K Wilgus, B.S. Hastings, C.A Ross, H.W. Posamentier, J. van Wagoner and C.G.St.C. Kendall (eds.). Society of Economic Paleontologists and Mineralogists Special Publication 42, p. 125-154.

Price, R.A. 1981. The Cordilleran foreland thrust and fold belt in the southern Canadian Rocky Mountains. In: Thrust and nappe tectonics. K.R. McClay and N.J. Price (eds.). Geological Society of London Special Publication 9, p. 427-448.

Rouble, R. 1994. Sedimentology and allostratigraphy of Falher members A and B of the lower cretaceous Spirit River formation, Northwest Alberta, Canada. MSc thesis, McMaster University, Hamilton, Ontario, 199p. and Walker, R. 1997. Sedimentology, high-resolution allostratigraphy, and key stratigraphic surfaces in Falher Members A and B, Spirit River 
Formation, West-Central Alberta. In: Petroleum Geology of the Cretaceous Mannville Group Western Canada, S.G. Pemberton and D.P. James (eds.). Canadian Society of Petroleum Geologists, Memoir 18, p. 1-29.

Ryer, T.A. 1984. Transgressive-regressive cycles and the occurrence of coal in some Upper Cretaceous strata of Utah, U.S.A. In: Sedimentology of Coal and Coal-Bearing Sequences, Rahmani, R.A., and Flores, R.M. (eds.). International Association of Sedimentologists, Special Publication v. 7, Blackwell Scientific Publications, Oxford, p. 217-227.

Shanley, K.W. and McCabe, P.J. 1994. Perspectives on the sequence stratigraphy of continental strata. American Association of Petroleum Geologists Bulletin, v. 78, p. 544-568.

Smith, D.G., Zorn, C.E. and Sneider, R.M. 1984. The paleogeograpahy of the Lower Cretaceous of western Alberta and northeastern British Columbia in and adjacent to the deep basin of the Elmworth area. In: Elmworth - Case Study of a Deep Basin Gas Field, Masters, J.A. (ed.). American Association of Petroleum Geologists Memoir 38, p. 79-115.

Snedden, J.W. and Kersey, D.G. 1981. Origin of San Miguel lignite deposit and associated lithofacies, Jackson Group, south Texas. American Association of Petroleum Geologists Bulletin. v. 65, p. 1099-1109.

Sprague, A.R., Patterson, P. E., Hill, R.E., Jones C.R., Campion K.M., Van Wagoner, J.C., Sullivan, M.D., Larue, D.K., Feldman, H.R., Demko, T.M., Wellner, R.W. and Geslin, J.K. 2002. The physical stratigraphy of fluvial strata: A hierarchical approach to the analysis of genetically related stratigraphic elements for improved reservoir prediction. American Association of Petroleum Geologists Annual Meeting, Houston, Texas. p. 167.

Stott, D.F. 1968. Lower Cretaceous Bullhead and Fort St. John Groups between Smoky and Peace Rivers, Rocky Mountain Foothills, Alberta and British Columbia. Geological Survey of Canada, Bulletin 152, 279p.

1975. The Cretaceous system in northeastern British Columbia. In: The Cretaceous system in the Western Interior of North America. W.G.E. Caldwell (ed.). Geological Association of Canada. Special Paper 13, p. 441-467.
1982. Lower Cretaceous Fort St. John Group and Upper Cretaceous Dunvegan Formation of the Foothills and Plains of Alberta, British Columbia, District of Mackenzie and Yukon Territory. Geological Survey of Canada, Bulletin v. 328, 124p.

Tasch, K.H. 1960. Die Möglichkeiten der Flörgleichstelling unter Zuhilfenahue von Flözbildungsdiagramme. Berhau-Rundschau v. 12, p. 153-157.

Taylor, D.R. and Walker, R.G. 1984. Depositional environments and paleogeography in the Albian Moosebar Formation and adjacent Gladstone and Beaver Mines Formations, Alberta. Canadian Journal of Earth Sciences v. 21 , p. $698-714$

van Hinte, J.E. 1976. A Cretaceous time scale. The American Association of Petroleum Geologists Bulletin, v. 60, p. 498-516.

van Wagoner, J.C., Mitchum, Jr. R.M., Campion, K.M. and Rahmanian, V.D. 1990. Siliciclastic sequence stratigraphy in well logs, cores and outcrops: concepts for high resolution correlation of time and facies. The American Association of Petroleum Geologists Methods in Exploration, Series 7, $64 \mathrm{p}$.

Wadsworth, J., Boyd, R., Diessel, C., Leckie, D. and Zaitlin, B. 2002. Stratigraphic style of coal and non-marine strata in a tectonically influenced intermediate accommodation setting - the Mannville Group of the Western Canadian Sedimentary Basin, south-central Alberta. Bulletin of Canadian Petroleum Geology, v. 50, p. 507-541.

Zaitlin, B.A., Potocki, D., Warren, M.J., Rosenthal, L. and Boyd, R. 2002. Depositional styles in a low accommodation foreland basin setting: an example from the Basal Quartz (Lower Cretaceous), southern Alberta. Bulletin of Canadian Petroleum Geology, v. 50, p. 31-72.

Manuscript received: October 18, 2002

Revised manuscript accepted: April 22, 2003 